\begin{tabular}{lcccccccccccccccccccccccccc}
\hline A C C & T & A & A & R & C & H & A & E & O & L & O & G & I & C & A & & C & A & R & P & A & T & H & I & C & A \\
VOL. LV & (2020): & $9-38$ & & & & & & & & & & & & & & & & & & & PL & ISSN & $0001-5229$ \\
\hline
\end{tabular}

DOI 10.4467/00015229AAC.20.002.13507

\author{
JACEK ANDRZEJOWsKI ${ }^{\bullet}$
}

\title{
The Eastern Zone of The Przeworsk culture - AND WHAT IT COMPREHENDS
}

\begin{abstract}
In phase B1, and very prominently - in phase B2 of the Roman Period, tribal groups of the north-eastern territories of the Przeworsk culture displayed a number of characteristic regional elements. These elements are mostly seen in female outfits that become much richer and more varied than elsewhere within the Przeworsk culture territory. The features specific for the Eastern Przeworsk Zone, like e.g., a very high frequency of dress elements made of copper alloys, would be largely the effect of mutual relations of these people with communities of the Wielbark culture from Eastern Pomerania. Though outwardly only ethnographic, this specificity of the material culture may have deeper underlying causes, since starting with phase B1, there is evidence of two basic types of Eastern Przeworsk cemeteries. In both cases, the women's grave furnishings display general Eastern Przeworsk characteristics. In cemeteries of the first group weapon graves disappear already in early phase B1. These cemeteries fell out of use before the end of phase B2 and reflect the full, or nearly full withdrawal of the 'Przeworsk' community from that area. The second group form Przeworsk cemeteries with 'standard' weapon graves. From phase B2/C1 on, the Wielbark culture newcomers continued to use many of these cemeteries. Many of them were then continuously used from phase B2/C1 by the Wielbark culture newcomers. It appears that a part of the Przeworsk population from the Eastern Zone probably joined Gothic (Wielbark) tribes then moving south. Recently many brooches recognized traditionally as definitely ethnographic markers of the Przeworsk culture (types Almgren 43 and Almgren 129) have been registered in the western provinces of nowadays Ukraine. However, these finds are already much more numerous than those from the 'core' territory of the Przeworsk culture - for the time being, this phenomenon seems to be inexplicable.
\end{abstract}

Keywords: Eastern Zone of the Przeworsk culture, Roman Period, cemeteries, brooches, weapon graves

The material culture of tribal groups which occupied a large area in Central Europe from phase A1 of the Late Pre-Roman Period until phase D1 of the Migration Period - or, from the second century BC until the first half of the fifth century AD - is known to archaeologists as the Przeworsk culture (recently see e.g., Godłowski 1985; 1992a; Dąbrowska 2003; Mączyńska 2003; Andrzejowski, Kokowski, Leiber 2004; Andrzejowski 2010; Maciałowicz 2016; Kontny 2016; Rodzińska-Nowak 2016; older literature there).

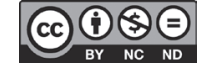




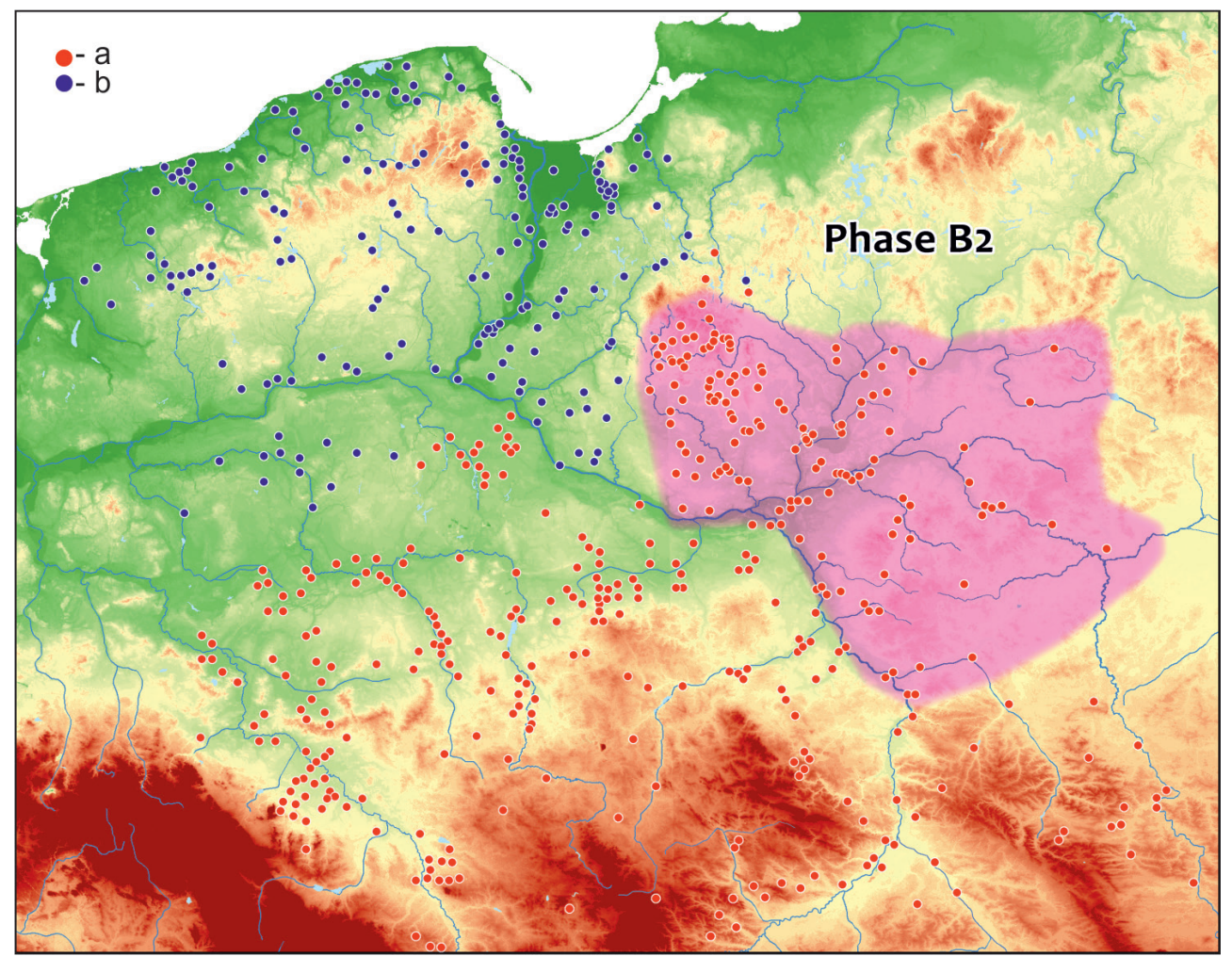

Fig. 1. Przeworsk (a) and Wielbark (b) culture sites well-dated to phase B2, with approximate range of the Eastern Przeworsk Zone (after Andrzejowski 2019)

In phase $\mathrm{B} 1$, and very prominently - in phase B2, a culture previously quite uniform in its archaeological outlook obviously starts to differentiate. This is evidently more than anywhere else in its eastern, or - to be more precise - northeastern territories, today, areas in north and east Mazowsze (Mazovia), and south Podlasie (Podlachia), to the east of the Vistula and to the north of the Wieprz River (Fig. 1).

This material culture recorded in this settlement zone, one that I propose to call the Eastern Zone of the Przeworsk culture (Andrzejowski 2001a; 2001b; 2010, 73-75, fig. 18; 2019, 228-230, fig. 2; Kontny 2016, 167-168; cf. Okulicz 1965a; 1970; Dąbrowska 1981; Godłowski 1985, 62-66; 1992a, 30) - Eastern Przeworsk Zone for short - displays a number of characteristic elements. I have discussed them before, on many different occasions, so let me only recall them in brief.

The dissimilarity of the Eastern Przeworsk Zone is the most apparent in women's outfits, which become much richer and more varied than elsewhere in 
the Przeworsk culture territory and include a very high percentage of copper alloy elements, or almost fully consist of bronzes and brasses. Next to standard forms brooches, dress pins and metal belt fittings we find a large quantity of bracelets (Andrzejowski 1994a; 2001a, 71-74, fig. 13), worn in pairs; these, next to ordinary plain bracelets, include a local type Kamieńczyk ${ }^{1}$ (Andrzejowski 1994a, 320-321, figs. 5-7; 2001a, 72-73, fig. 13) (Fig. 2), and shield-headed

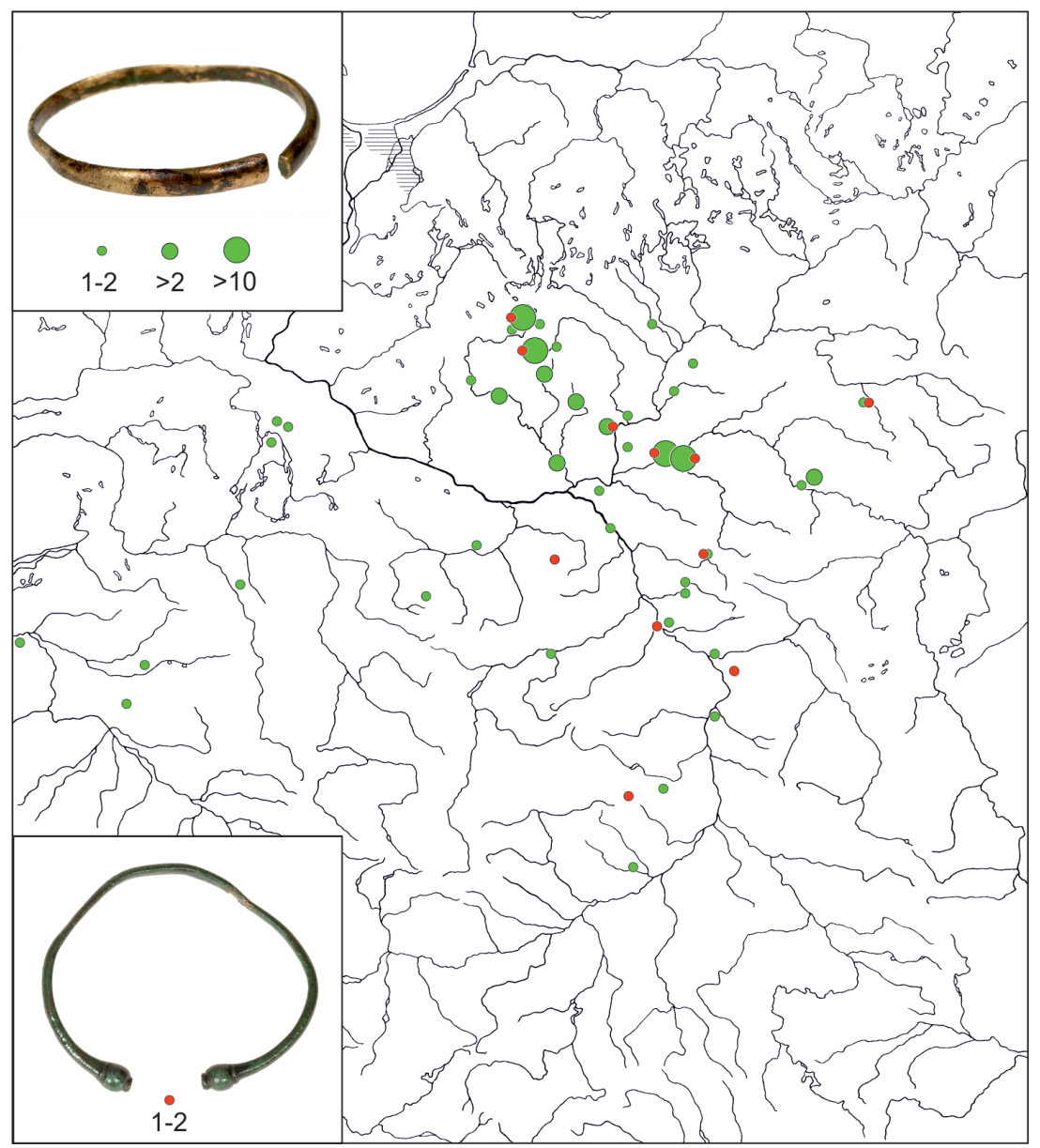

Fig. 2. Distribution of plain (green) and type Kamieńczyk (red) bracelets within the Przeworsk culture area (after Andrzejowski 2001a)

\footnotetext{
${ }^{1}$ The type had been distinguished and introduced by Teresa Dąbrowska (1981, 48, fig. 3).
} 


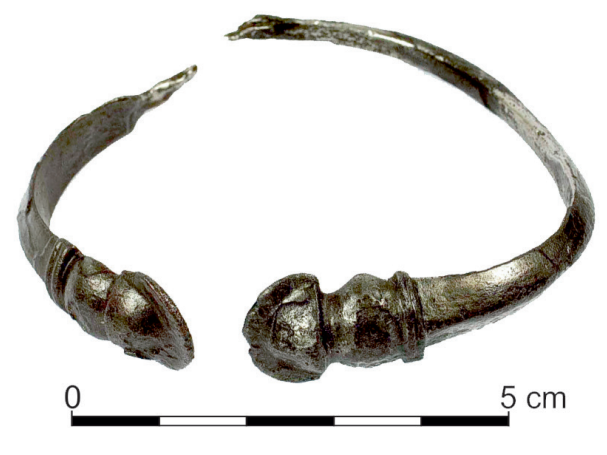

Fig. 3. A unique shield-headed bracelet of Pomeranian type forged of iron, found in a Przeworsk culture cemetery at Kołacz, eastern Mazovia. Photo R. Sofuł bracelets of the Pomeranian type (Andrzejowski 1994a, 321-322, figs. 8 \& 9; 2001a, 73-74. Cf. Blume 1912, 6471, figs. 78-88; Wójcik 1982; Cieśliński 2016, 246 (here as snake-headed); Beliavets, Przybyła, Voroniatov 2018, 174-176, fig. 8) (Fig. 3). Found very often in graves are the remains of glass bead necklaces; however, cremation, which is dominant, if not actually the only form of the burial rite, reduces the likelihood of the survival in the archaeological record of complete necklaces of glass and amber beads ${ }^{2}$ and smaller items of jewellery (like pendants and S-clasps; Andrzejowski

1997, 109-113, fig. 8; 2001a, 70-71, figs. 11 and 12; Madyda-Legutko, RodzińskaNowak, Zagórska-Telega 2010) made of silver and gold and copper alloys.

The group of brooches is dominated by variants principally made of copper alloys (Dąbrowska 1981, 47; Andrzejowski 2001a, 61; 2019, 228). The Eastern Przeworsk Zone is one of the centres of the occurrence (and presumably, of the production) of eye brooches of the Prussian series (Andrzejowski 2001, 61-62, figs. 2 and 3; Andrzejowski, Cieśliński 2007, 282-286, figs. 4-6. Cf. Pfeiffer-Frohnert 1998; Twardo 2003; Mączyńska 2004, 213-215, maps 3 and 4, annex 3; 2011, 25-27, fig. 8) (Fig. 4). (This clear image has recently been slightly blurred by two mass finds of the Prussian series brooches: one of some 200 specimens from the Roman town Augusta Vindelicorum (Augsburg) in Raetia ${ }^{3}$, and another one of ca 60 specimens from a Przeworsk culture settlement at Sójkowo in Kujawy region ${ }^{4}$ - both are equally hard to understand, however, due to different reasons.) This zone is also the source of origin of two groups of brooches that are, positively, a marker of the local fashion; I mean the late strongly profiled brooches, type Liana 5 (Fig. 5), and the forms derivative from strongly profiled brooches, Mazowsze variant (Dąbrowska 1995, 1998, 151-153, figs. 2-4; Andrzejowski 2001a, 64-65, figs. 6 and 7; Andrzejowski, Cieśliński 2007, 289-292, figs. 11 and 12) (Fig. 6);

${ }^{2}$ See e.g., necklaces from Nadkole 2 in eastern Mazowsze preserved as a number of burnt or melted glass lumps (Andrzejowski 1998, 64, pl. CXV). The only beads to survive are the melon-shaped beads made of quartz ceramic (recently Höpken 2003; see also Born 1975).

${ }^{3}$ Personal comm. from Martina Pauli, Bayerische Landesamt für Denkmalpflege. Cf. Bakker 2002, 263-264, fig. 3; Voß 2007, 7, fig. 2; 2008, 343-346, fig. 1.

${ }^{4}$ Personal comm. from Ireneusz Jakubczyk PhD, Institute of Archaeology, University of Warsaw.

5 The most recent analysis remains unpublished (Andrzejowski 2009, 243-262, pls. 5.1-5.15, annex 5). 


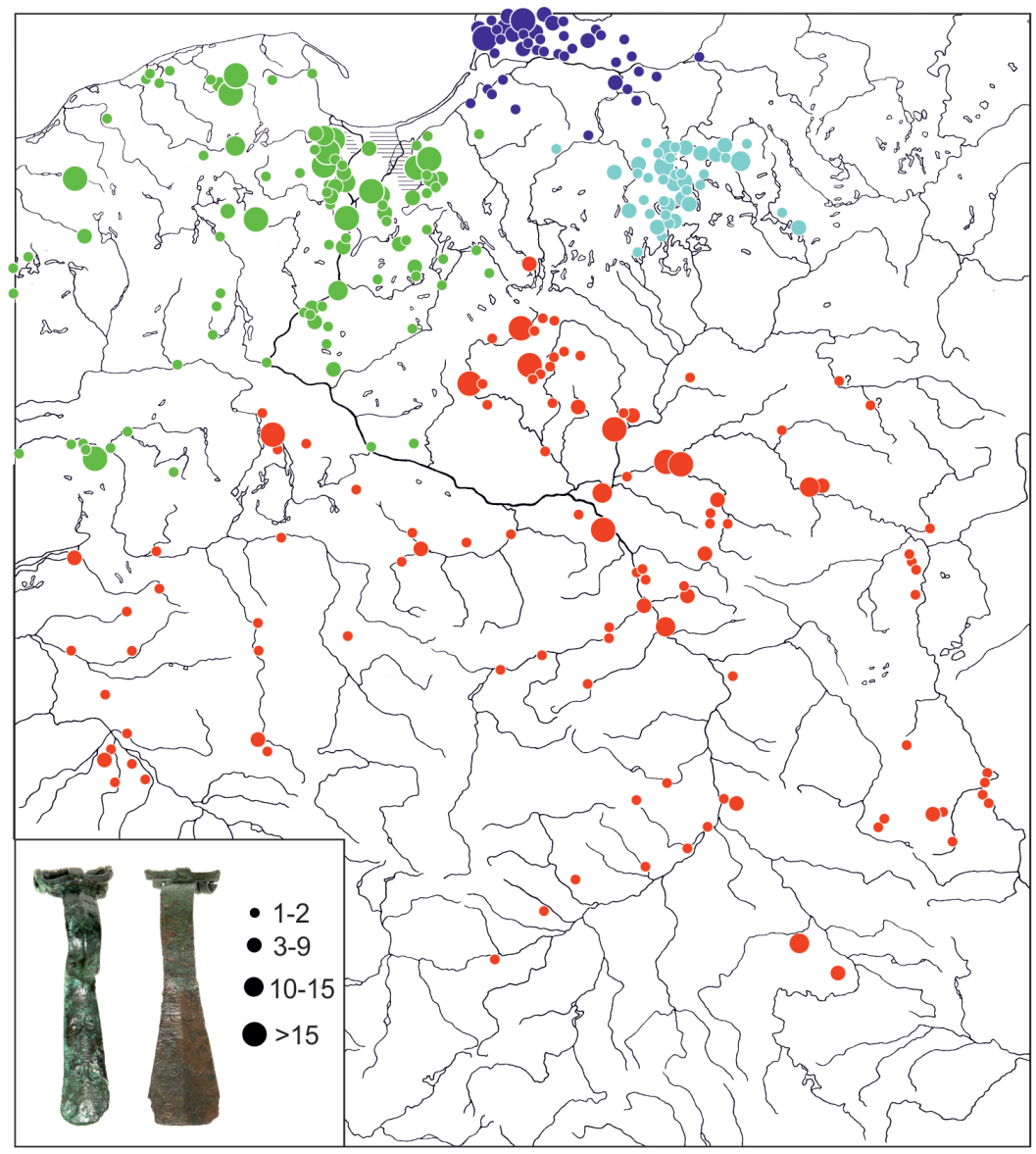

Fig. 4. Distribution of eye brooches of the Prussian series within the Przeworsk (red), Wielbark (green), and the West Balt (dark and light blue) culture areas (after Andrzejowski \& Cieśliński 2007 - partly modified). Photo R. Sofuł

furthermore, mixed forms of Almgren's group II and group IV (Olędzki 1986; Andrzejowski 1994b; 2001a, 64-65, figs. 4 and 5) (Fig. 7). Also observed, and this despite the common cremation rite, is a relatively high frequency of silver and gold. These metals are used either as decoration of copper alloy and iron items (first of all, brooches, decorated with filigree, inlay or repoussé foil; see e.g., Madyda-Legutko, Rodzińska-Nowak 2017), or in making personal ornaments (pendants and S-clasps; exceptionally, also bracelets) ${ }^{6}$.

\footnotetext{
${ }^{6}$ For silver and gold pendants see e.g., Andrzejowski 2001a, 70; Madyda-Legutko, Rodzińska-Nowak,
} 


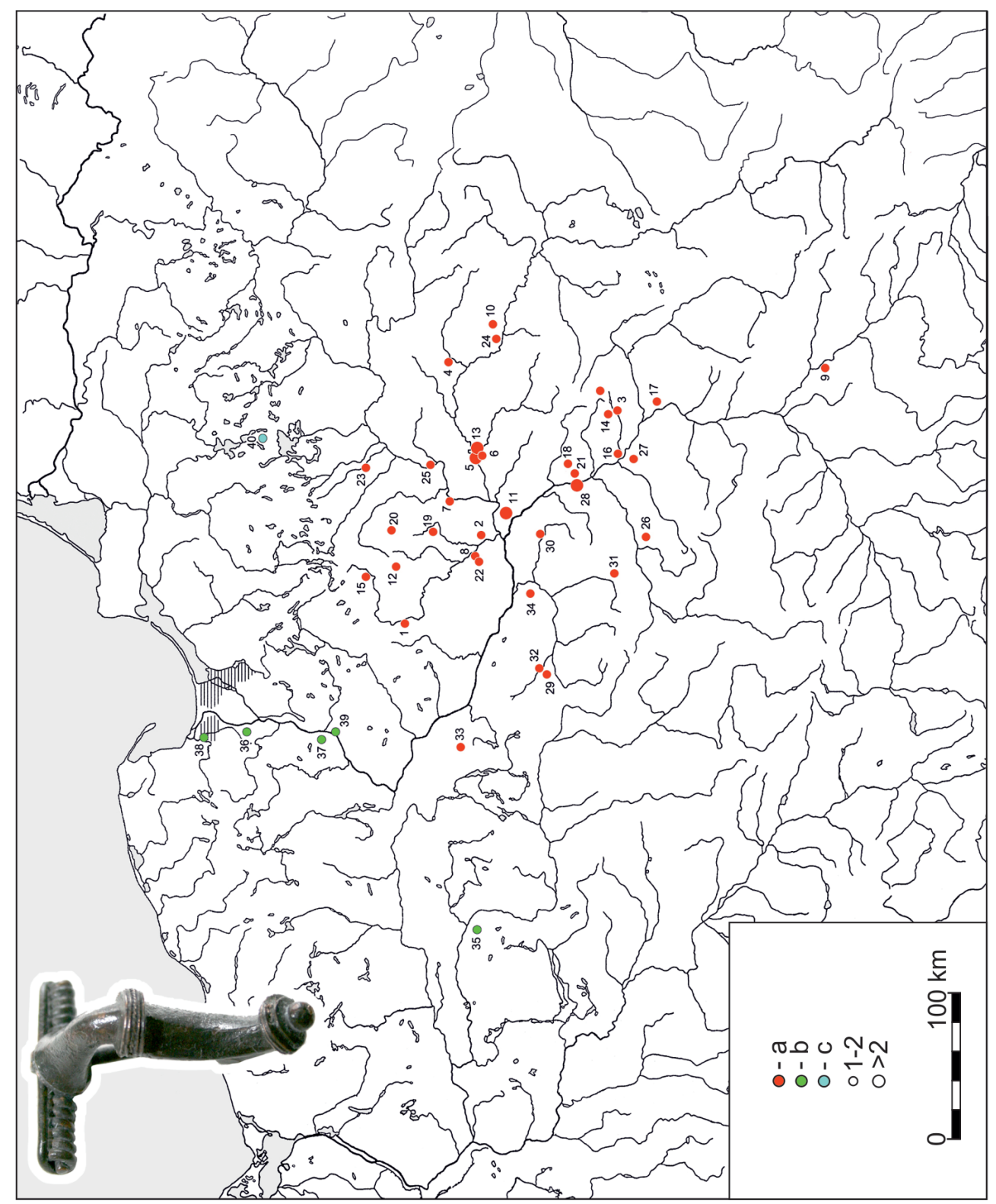

Fig. 5. Distribution of strongly profiled brooches type Liana 5 within the Przeworsk (a), Wielbark (b), and the West Balt (c) culture areas (after Andrzejowski 2009 - for the Przeworsk culture, partly modified). Photo J. Andrzejowski 


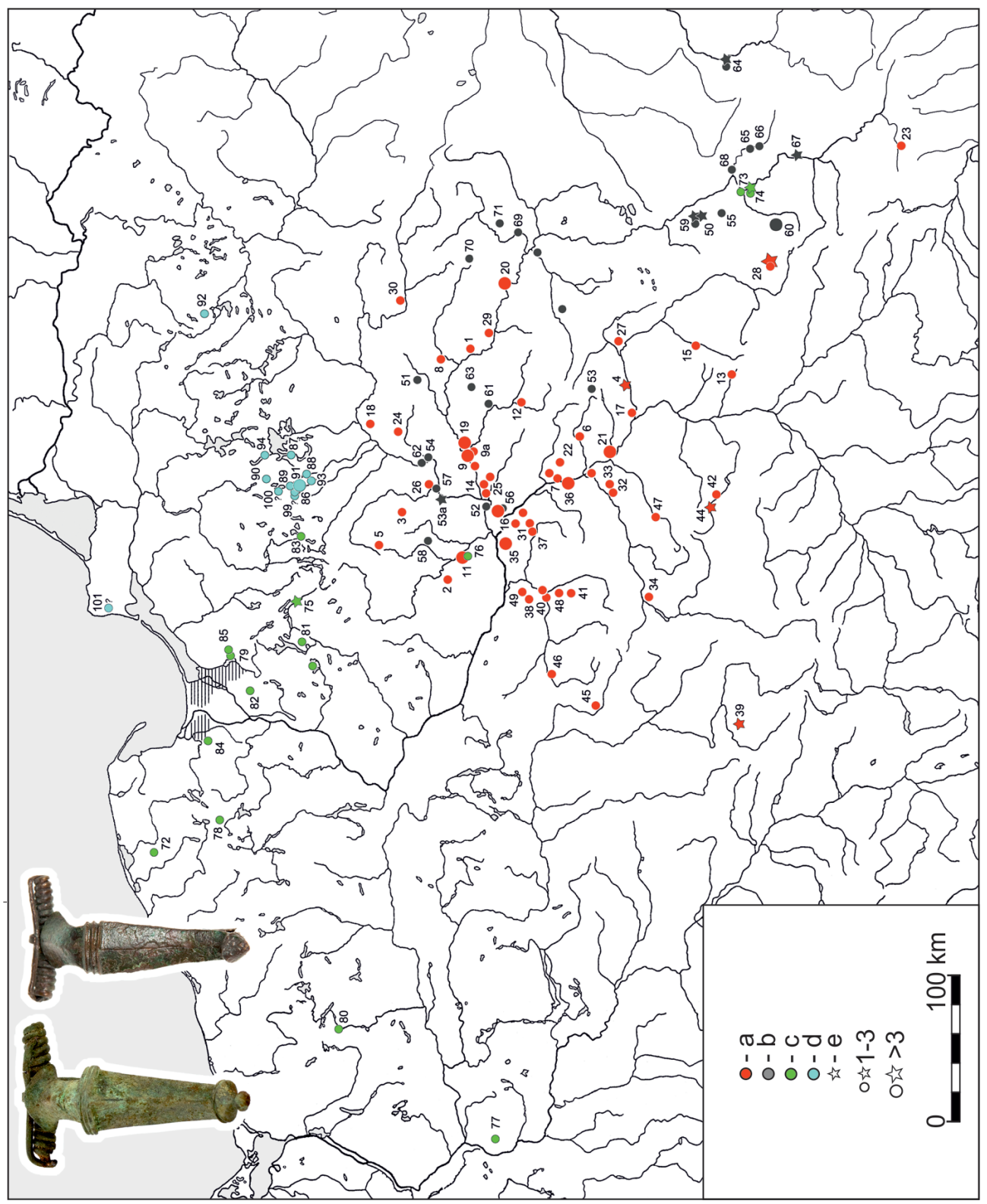

Fig. 6. Distribution of strongly profiled brooches of the Mazowsze variant (incl. Topornica variety - e) within the Przeworsk (a), Wielbark (c), and the West Balt (d) culture areas; stray finds of either Przeworsk or Wielbark culture brooches are marked in black (b) (after Andrzejowski 2009 - for the Przeworsk culture, partly modified). Photo R. Sofuł 


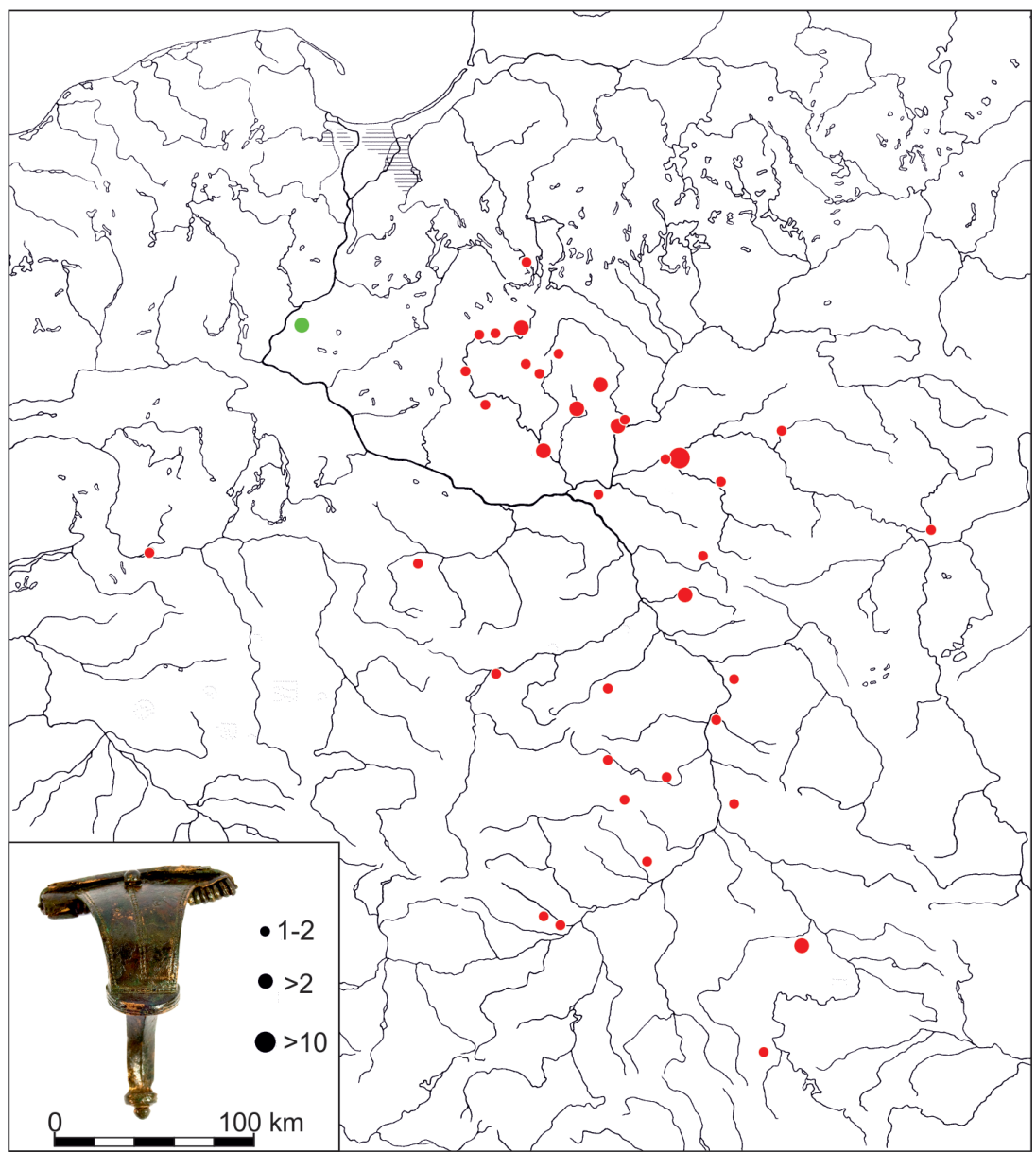

Fig. 7. Distribution of mixed forms of brooches Almgren's groups II and IV, eastern series within the Przeworsk (red), Wielbark (green) culture areas (after Andrzejowski 2001a - modified). Photo R. Sofuł

These features specific for the Eastern Przeworsk Zone would be largely the effect of mutual relations of the north-eastern Przeworsk culture groups with communities of the Wielbark culture established in Eastern Pomerania in the broad sense $e^{7}$. This specificity of the material culture, outwardly only ethnographic,

Zagórska-Telega 2010. For silver S-clasps see Andrzejowski 1997, 110 (and two more items from unpublished excavation). For the only silver plain bracelet see Andrzejowski 1994a, 319; Dłubakowski 2005, 93.

${ }^{7}$ On the Wielbark culture recently see e.g., Mączyńska 2007; Kokowski 2007, 39-197; 2010; Cieśliński 2016; older literature quoted there. 
may have a deeper underlying causes. This is because - starting with phase B1 - there is evidence in the Eastern Zone of two basic types of cemetery (see Andrzejowski 2019, 230-235). In each case, the women's grave furnishings display Eastern Przeworsk characteristics; differently, male burials which show significant differences.

In the cemeteries of the first group, burials containing weapons disappear still in phase B1, and even earlier, in phase A3/B1, in many graves we find only fragments of military gear, according to the pars pro toto principle ${ }^{8}$. These cemeteries fall out of use before the end of phase B2, their possibly 'Wielbark' episode is always preceded by a break, or by a slender or poorly recoverable horizon of the functioning of the cemetery ${ }^{9}$. It is understood to reflect the full, or nearly full withdrawal of the 'Przeworsk' community from that given area.

The second group are 'standard' Przeworsk cemeteries, with male graves containing weapons which are deposited either up to the time that the gravesite was abandoned ${ }^{10}$, or to the end of 'Przeworsk' episode ${ }^{11}$. In the latter case, we need to take into account unbroken use of that cemetery, and even, during phase B2/C1-C1a, the use of the grave-site by both 'Przeworsk' and 'Wielbark' communities (Andrzejowski 1989; 2001b, 108-109, fig. 9; 2007, 233-234; 2019, 230, fig. 4).

The cemeteries of the first group are not found outside the north-western part of the Eastern Przeworsk Zone, where there are almost no cemeteries of the second model; the latter are present everywhere in the rest of the Eastern Przeworsk territory. Eastern Przeworsk settlement endures until the decline of phase B2 and the onset of phase B2/C1-C1a. The youngest reliably dated 'pure' Przeworsk burials in this area belong to the 'pure' stage C1a ${ }^{12}$ (Fig. 8).

In phase B2/C1, we start to record cemeteries of the Wielbark culture all over the territory of the late Eastern Przeworsk Zone (Wołagiewicz 1988, fig. 3; Godłowski 1992b, 64-66, map 5; 1994, 73, fig. 3; Kokowski 1999, 184, maps 2

\footnotetext{
${ }^{8}$ Grave 192 from the cemetery at Modła 2 in northern Mazowsze may serve as a good example. Except for pottery, an iron spur, a razor, and an awl or a pin fire steel, it contained three short iron rivets presumably from a tang of a single-edged sword, three iron clasps and a clasp with suspension ring from a sword scabbard, fragment of an iron shield handle with a rivet, three big iron rivets from a shield boss, a small piece of a shield rim fitting made of copper alloy (Andrzejowski 2009, 171-172, pls. 3.88/192-3.89/192; cf. Grzymkowski 2005, fig. 10). For the phenomenon itself recently see Maciałowicz, Woźniak 2015.

${ }^{9}$ E.g., cemeteries at Niedanowo 2 (Ziemlińska-Odojowa 1999; cf. Andrzejowski 2009, 358-377, pls. 6.3-6.10; 2019, 230-231, fig. 5) and at Modła 2 (Grzymkowski 1986; 2005; Andrzejowski 2006a; 2009, 11-237, pls. 1.1-1.5, 2.15-2.10, 3.1-3.155; 2019, 230, fig. 6), both in northern Mazowsze.

${ }^{10}$ E.g., neighbouring cemeteries at Kamieńczyk 1 (Dąbrowska 1997) and Nadkole 2 (Andrzejowski 1998), on the confluence of Liwiec and Bug Rivers in eastern Mazowsze.

${ }_{11}$ E.g., cemeteries at Kołozą 3 in north-western Mazowsze (unpublished: Andrzejowski 2006b; 2009, 384-393, pls. 6.11-6.26; see also e.g., Tomaszewska 1988; Andrzejowski 2019, 233, fig. 7) and Krupice IA in southern Podlasie (Jaskanis 2005).

${ }^{12}$ E.g., grave 55 from Stare Załubice on the lower Narew River in eastern Mazowsze (Andrzejowski 2005, 237, fig. 8), and grave 1 in stone circle from Rostki in northern Mazowsze (Okulicz 1965b; 1970, 441).
} 

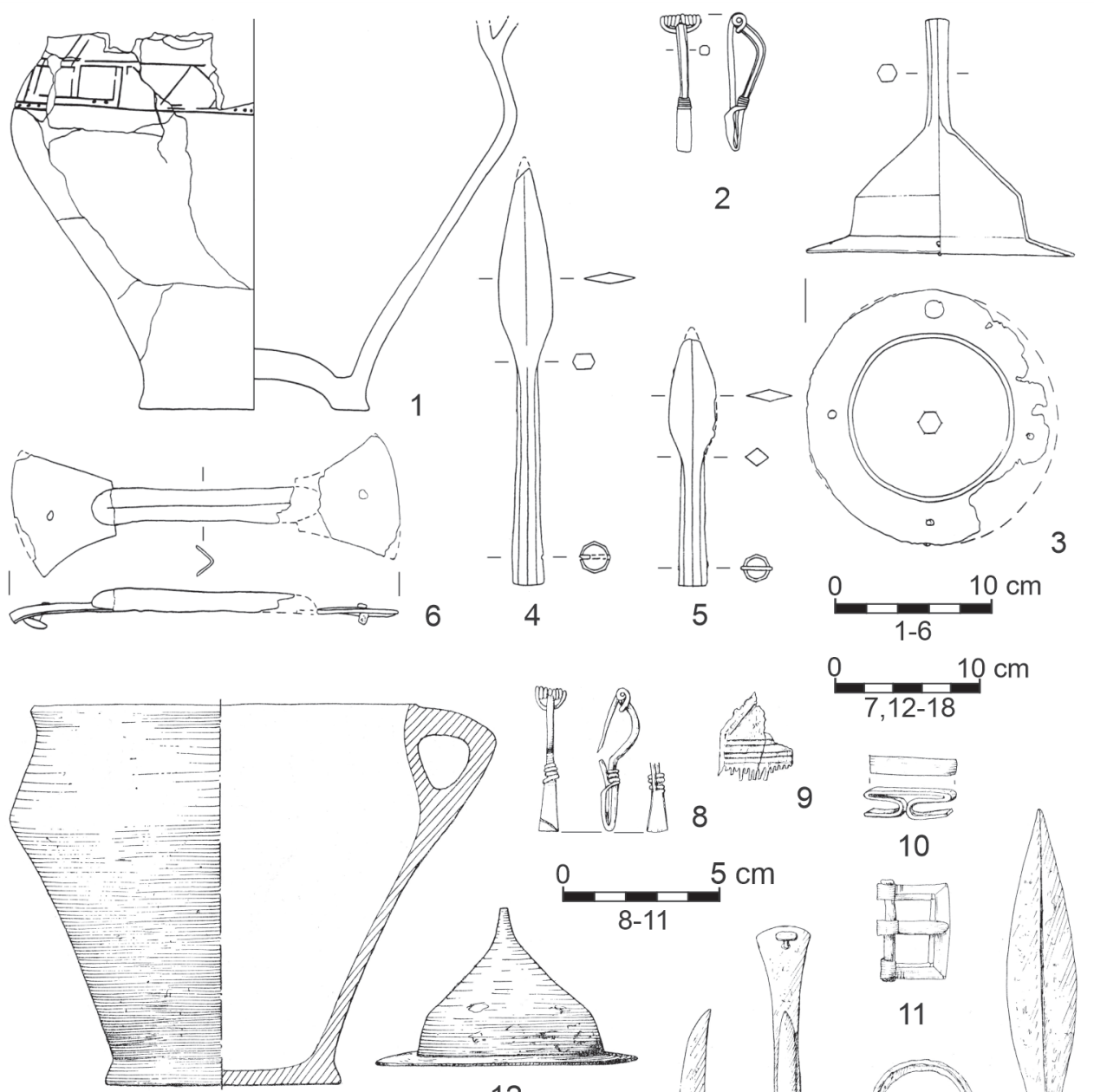

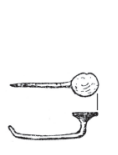

13
7

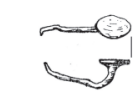

14

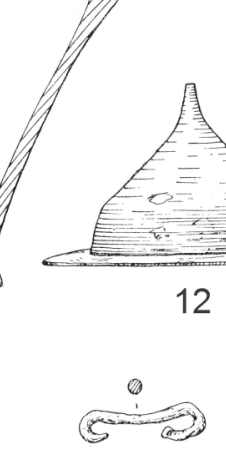

15

12
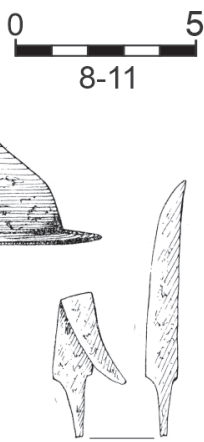

16
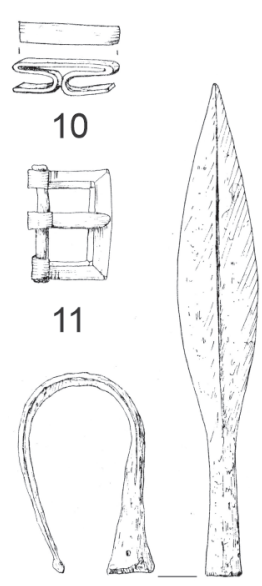

18

Fig. 8. Closed finds from the Eastern Przeworsk Zone well dated to the stage C1a.

1-6 - Załubice, grave 55, eastern Mazovia; 8-18-Rostki, grave 1 in stone circle 6, northern Mazovia (after: 1-6 - Andrzejowski 2005; 8-18-Okulicz 1965b) 
and 3; Andrzejowski 2007, 232; cf. Belâvec 2016, 390-396, fig. 1) (Fig. 9); these may be either newly-established ${ }^{13}$, set up on the site of a previously abandoned Eastern Przeworsk cemetery ${ }^{14}$, or continue an older grave-field ${ }^{15}$; taking into consideration a known number of the latter it seems rather to be a rule than an exception (Fig. 10).

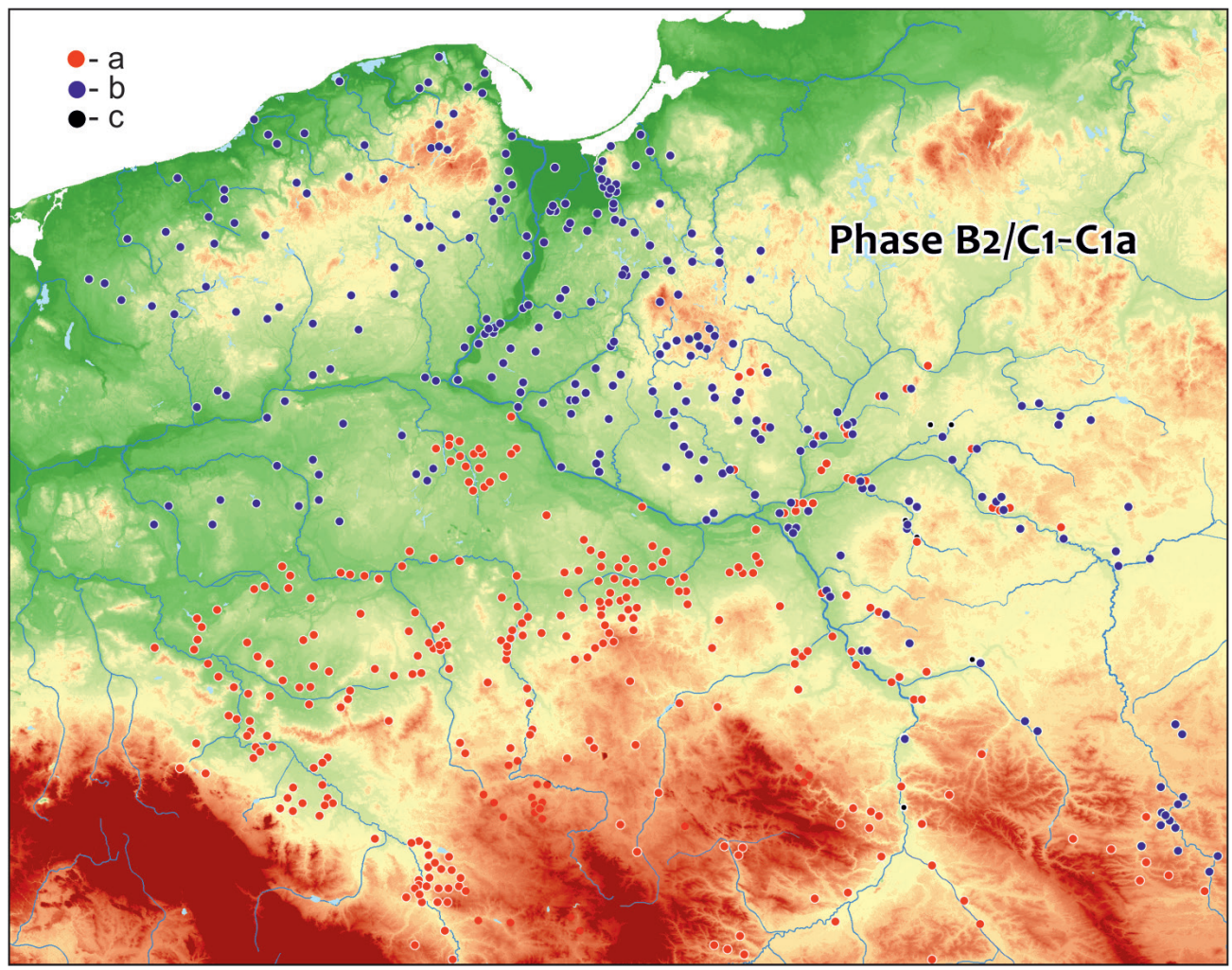

Fig. 9. Przeworsk (a) and Wielbark (b) culture sites well-dated to phase B2/C1-C1a; stray finds of either Przeworsk or Wielbark culture brooches are marked in black (c)

(after Andrzejowski 2019)

${ }^{13}$ E.g., Kłoczew 1 in south-eastern Mazowsze (Balke 1971), Brulino-Koski 1 in south-western Podlasie (Kempisty 1968), and Brèst-Tryšyn/Брэст-Трышын in south-western Belarus (Kuharenko 1980; Belâvec 2007).

${ }^{14}$ E.g., Kleszewo 1 on the lower Narew River in northern Mazowsze (unpublished: Andrzejowski 2009, 397-404; now studied by Marcin Woźniak from Museum of Ancient Mazovian Metallurgy in Pruszków, see Woźniak 2016; 2019), Modła, and Niedanowo (for both see footnote 9).

15 E.g., Kołoząb 3 (see footnote 11) and Łajski 3 (unpublished: Andrzejowski 2009, 404-415, pl. 6.27; 2019, 233, fig. 8) on at the lower Narew River. 


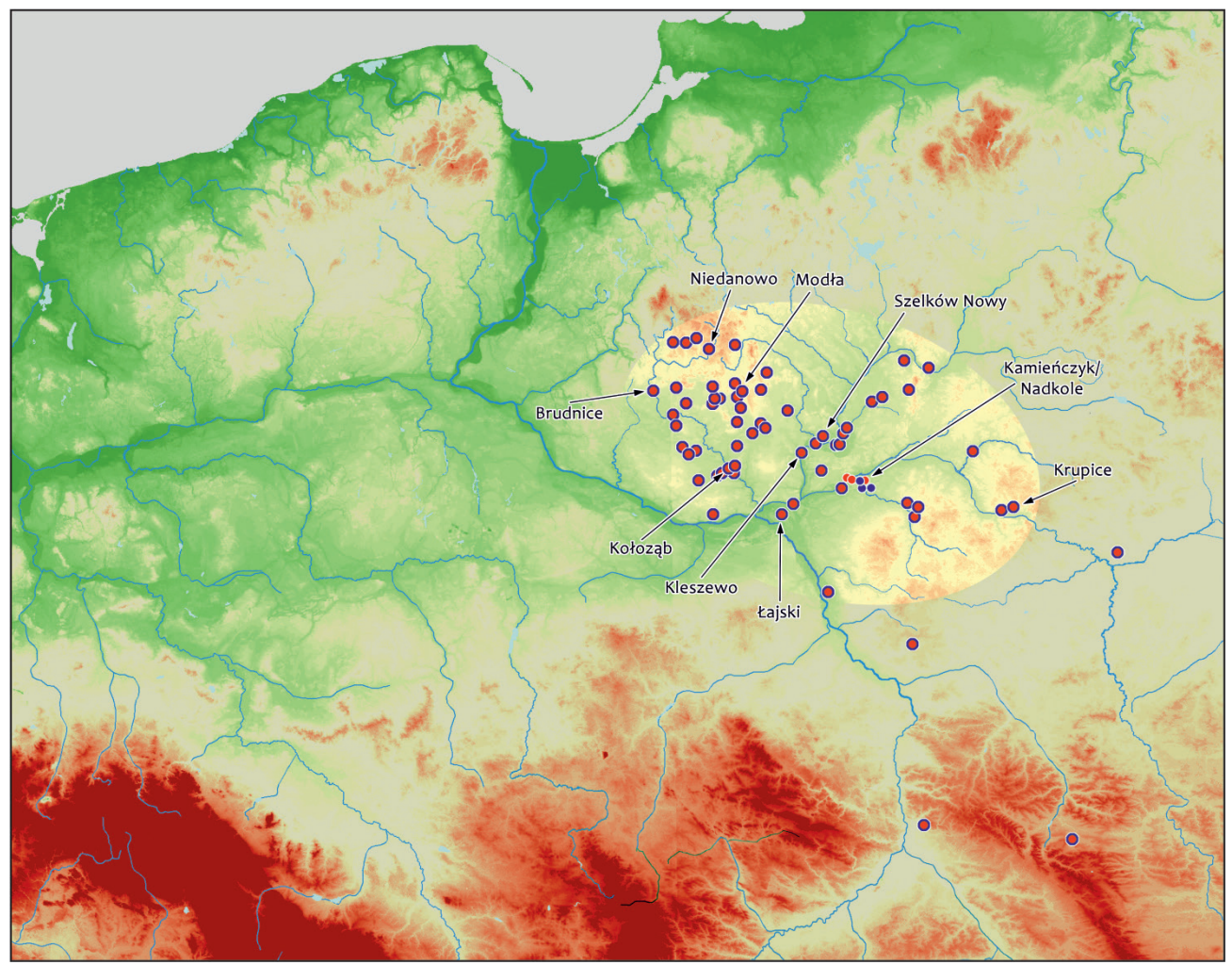

Fig. 10. Cemeteries of the Przeworsk culture later used by the Wielbark culture people (after Andrzejowski 2019)

The geographical range of the Eastern Przeworsk Zone in the north and east is obvious, and corresponds to a culture boundary; in the west, it is understood to extend to the Vistula; on the other hand, in the south this range is fuzzy and hard to delimit conclusively ${ }^{16}$. This is because the Eastern Przeworsk Zone is more of a culture phenomenon than a closely defined territorial group of this culture.

It appears that a part of the Przeworsk population from the Eastern Zone joined the southward Przeworsk wave when it expanded into eastern Slovakia, north-eastern Hungary and northern Romania (See e.g., Godłowski 1985, 70-71, 81-84, 105-106, maps 5 and 6; 1992b, 63-66, maps 5 and 6; 1994; Kozak 1993, 65-66, map 14; 2008, fig. 81; Kokowski 1999; 2007, maps 4-7). The cemeteries

${ }^{16}$ Cf. spatial structure of the Przeworsk culture settlement in the Lublin region (Kokowski 1991, 183-188, fig. 88). 
known from Prusiek near Sanok (see e.g., Madyda-Legutko, Rodzińska-Nowak, Zagórska-Telega 2009; 2013, 411-416; Madyda-Legutko, Rodzińska-Nowak 2012; older literature quoted there), Ostrów near Przemyśl (Lasota, Stempniak 2015), and to some extent, Gać near Rzeszów (Hadaczek 1909; Lasota 2011; 2014), both in south-eastern Poland, could be the evidence of this shift. This expansion started still in phase B2, and only reaches its peak at the beginning of the Late Roman Period. Another part of the population probably joined Gothic tribes then moving south. Until phase $\mathrm{C} 1 \mathrm{a}$ (perhaps $\mathrm{C} 1 \mathrm{~b}$ ?), the Przeworsk population remained in place in the eastern part of the Lublin Region, between the Wieprz, Vistula and San Rivers, and in a densely settled pocket around present-day Lviv (e.g., Kokowski 1991, 186-188, fig. 89; Godłowski 1992a, 31, map 5; Kozak 1984; 1993; Oniŝuk 2018, 115-138). It seems that the Eastern Przeworsk Zone is a reflection of an episode that was part of a major cultural change taking place between the first and the third centuries $\mathrm{AD}$ between the Baltic and the Black Sea. From the perspective of the Wielbark and Chernyakhov cultures, or, in another words, of the so-called Gothic circle, this process was noticed a long time back by Yurij Kuharenko (Kuharenko 1980, 64-76), and next analysed in-depth by Mark Shchukin (recently Ŝukin 2005) and Andrzej Kokowski (e.g., Kokowski 1999; 2007, 23-226).

New finds recorded recently in Ukraine, mostly its western regions, shed more light on this process, although, obviously, we are still far from understanding it to our satisfaction. Unfortunately, nearly all of them come from illegal metal detecting ${ }^{17}$. Therefore, we can hardly compare the picture which appears from these finds with the results of archaeological fieldwork, or from surface surveys, but at least, made by professional archaeologists. Nevertheless, it is worth paying attention to two groups of brooches that date to the late phase B2 and to phases $\mathrm{B} 2 / \mathrm{C} 1-\mathrm{C} 1 \mathrm{a}$, in the assemblage of these finds.

The first group are assorted forms derivative from the strongly profiled brooches, characteristic for the Eastern Przeworsk Zone - the brooches of the Mazowsze variant, and its younger - presumably - variety Topornica (Andrzejowski 2009, 252-254, 259, pls. 5.5 and 5.13. Cf. Kuśnierz 2005, 235-237, pls. I:C, II:C.E and III:H) (Figs. 6, 11), which lacks an equally strong culture identification as the Mazowsze variant. Until recently, only a dozen-odd specimens of variety Topornica had been recorded, mostly from south-eastern Poland and the border area of Poland and Ukraine. Out of at least 50 brooches from these recent Ukrainian finds most were allegedly found in western regions of that country (Figs. 12,13). Their presence seems to confirm the movement through the area of

${ }_{17}$ A large number of such artefacts is auctioned online at Violity. Аукціон дла колекціонерів (https://auction.violity.com). Some has been recorded and published by Igor A. Bazhan (see the series KSAN. Korpus slučajnyh arheologičeskih nahodok, vol. 1, 5-9, Moskva 2011-2015). 


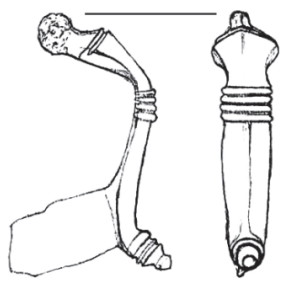

1
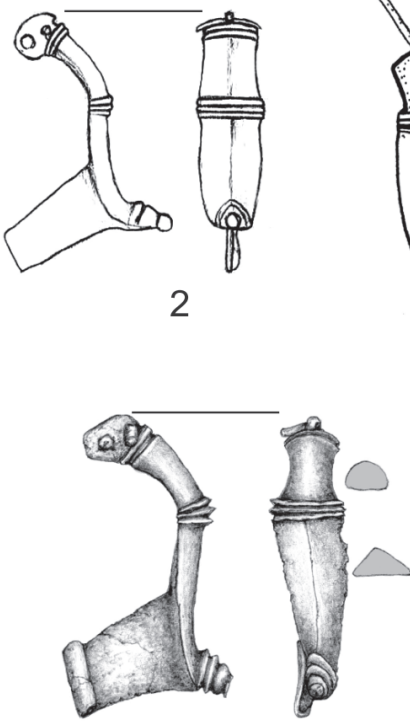

5

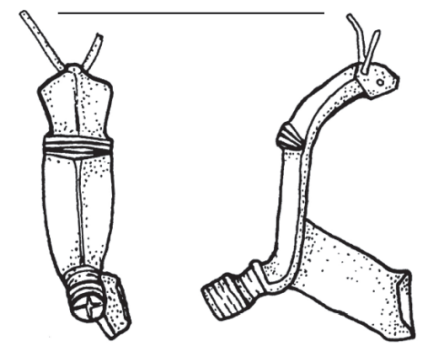

3

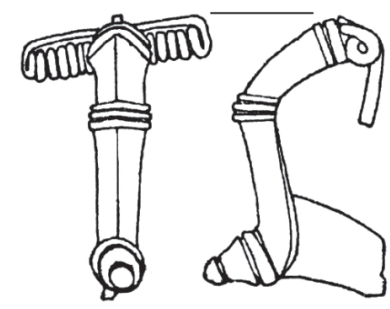

6
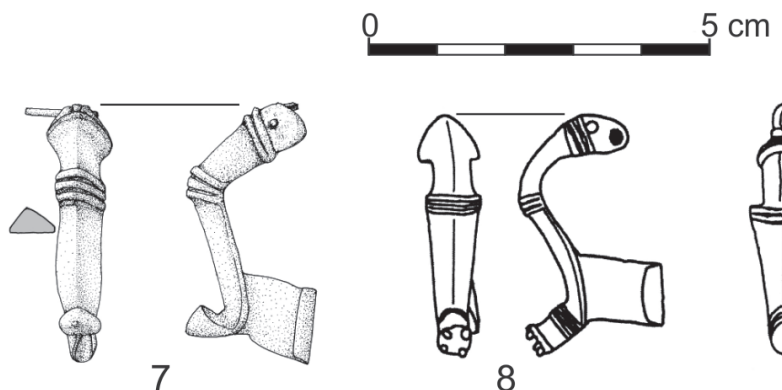

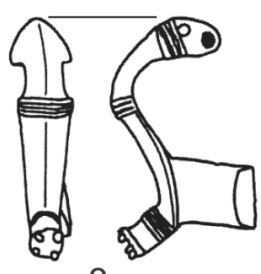

8

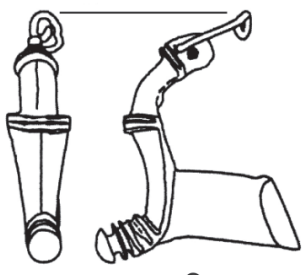

9

Fig. 11. Brooches of the Topornica variant from Poland (1-6) and western Ukraine (7-9).

1, 2 - Topornica, south-eastern Lublin Region; 3 - Tarkawica, northern Lublin Region; 4 - Wąchock, north-western Little Poland; 5 - Kleszewo, northern Mazowsze; 6 - Drążgów, northern Lublin Region; 7 - Sokal, northern Galicia; 8, 9 - Luck, south-western Volhynia.

(after: 3 - Kuśnierz 2005; 6 - Kokowski 1990; 8, 9 - Levada 2007).

Drawn by M. Juściński $(1,2)$, A. Potoczny $(4,7)$ and K. Dejtrowska (5)

groups of the Eastern Przeworsk population. Brooches described now as variety Topornica are regarded as the forms which later gave rise to the local variant of late brooches derivative of strongly profiled forms - type Vojtenki (Levada 2007, 243-246, figs. 8 and 9, cf. fig. 7:2.6.8.12 - variety Topornica); recently the known number of the latter significantly increases due to amateur metal detecting. 


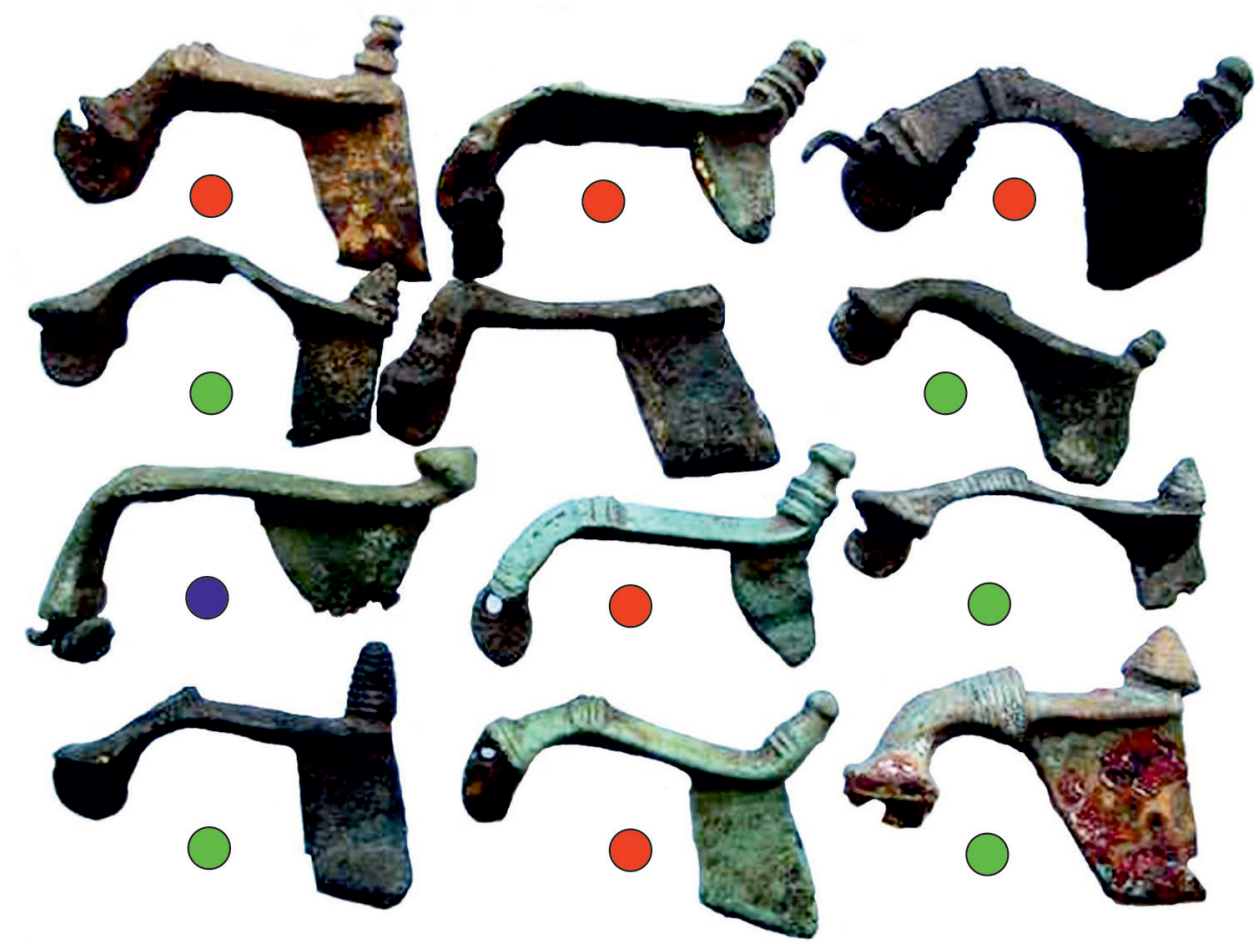

Fig. 12. A set of late strongly profiled brooches of the Mazowsze variant (dark blue) and its Topornica variety (red), and the Vojtenki type (green), supposedly from Ternopil Region in eastern Galicia (photo after https://auction.violity.com/). Not to scale

On the other hand I cannot explain the presence in western Ukraine of the second group of brooches, treated traditionally as definitely ethnographic markers of the Przeworsk culture - types Almgren 43 and Almgren 129. The series of Almgren 43 brooches is large, the series of Almgren 129 brooches - staggering ${ }^{18}$ (Andrzejowski 2017, 426).

The number of recorded Almgren 43 brooches in total is not too large - ten years ago, Magdalena Mączyńska listed just fifty, quite recently Jan Rajtár almost doubled this number (Mączyńska 2011, 41-42, fig. 16, list; Rajtár 2018); most of them comes from the Przeworsk culture sites ${ }^{19}$ and from Germanic sites on the

${ }^{18}$ Number of finds given below is valid for June, 2019.

19 Recently the first Almgren 43 brooch was discovered in the northern reaches of the Wielbark culture area (Natuniewicz-Sekuła 2018, 236, fig. 2:3). Admittedly, brooch of this type belongs to the $5^{\text {th }}$ century AD 'hoard' known from eastern Pomerania (Mączyńska 2011, 41, 348 F 41, pl. 7: F 41), however, the 'hoard' itself consists mostly of objects of Przeworsk culture origin (Mączyńska 2011, 


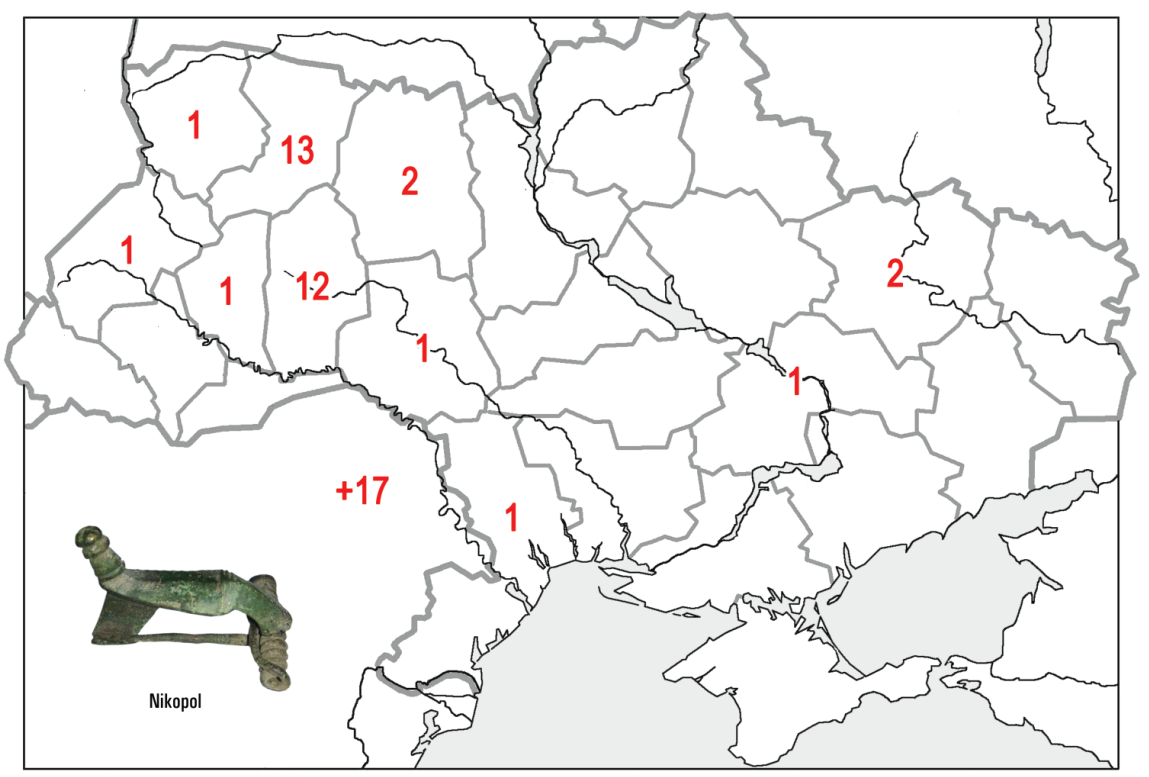

Fig. 13. Distribution of brooches variety Topornica known from online auctions (www.violity. com; status 06.2019) within the administrative regions (область) of Ukraine

Middle Danube (Fig. 14). (Single finds of this distinctive form has been appeared far from its native areas, in the Roman provinces, what in one case resulted in an amazing ancient 'repairing' of the damaged brooch ${ }^{20}-$ see Fig. 15). And now, from western Ukraine we have gained over forty further Almgren 43 specimens, all of them in copper alloy ${ }^{21}$, some decorated with repoussé gold or silver foil! The concentration of their finds in the west of that country did not surprise - at least, until we mapped them on our earlier distribution map of the Almgren 43 type and noticed that the two zones are separated by a fairly conspicuous zone where their finds were recorded in a very small number only (cf. Figs. 14 and 16).

We have a different situation when it comes to brooches of Almgren's group V, series 8 , with a rectangular aperture in the bow, classified as type 129 . The most

246-247). Another new finds come from Wandersleben in Thuringia (Walther 2018), Perkowo in Kujawy (Kurpiewski, Rakoczy 2015, 2, pl. 2:23), Rankovce in eastern Slovakia (Rákoš 2018), and Rakša in northern Slovakia (Pieta, Švihurová 2019, 112, fig. 2:5.6).

${ }^{20}$ Head of a copper alloy Almgren 43 fibula with a spring broken off and partly damaged catchplate had been joined (probably soldered) with a head of a copper alloy strongly profiled fibula, possibly Almgren 84 (cf. Vulić 2007; 2012, 109-110, 129, fig. 3, pl. III:1; see also a poster in: https:// www.academia.edu/5070576/The_southernmost_find_of_Almgren_43_fibula - access 20.07.2014).

${ }^{21}$ Iron brooches are missing probably because of settings used by most metal detectorists which eliminate this metal. The same applies for Almgren 129 brooches. 


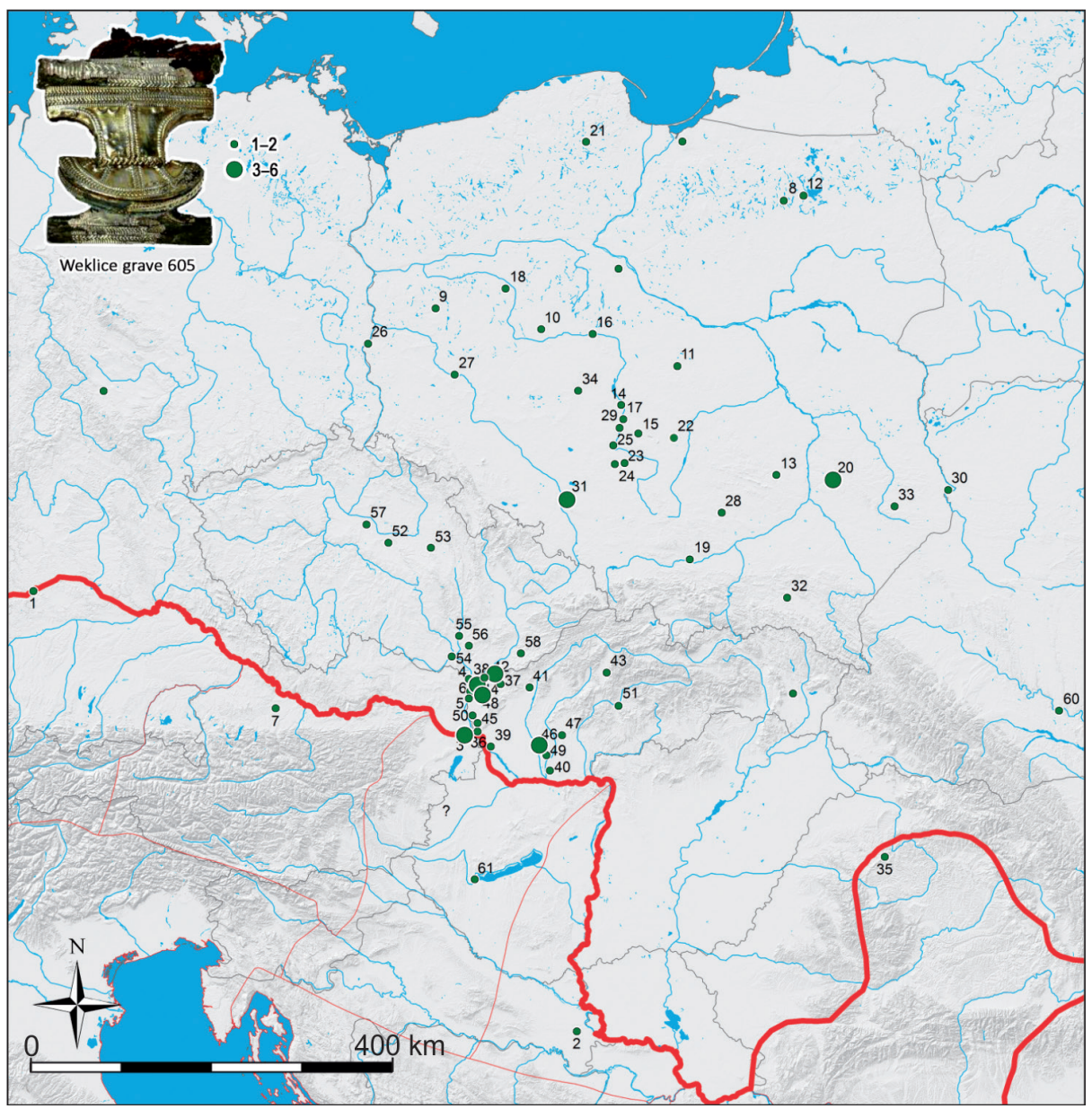

Fig. 14. Distribution of brooches type Almgren 43 (after Rájtar 2018 - modified).

Photo after Natuniewicz-Sekuła 2018

recent lists made by Magdalena Mączyńska (Mączyńska 2011, 58, fig. 25, list 15), with additionally, some input from Jan Rajtar (2013, 142-144; 2015, 380-383) and Jaroslav Tejral (2015, 45-49, figs. 1-5) for the Middle Danube region, and single finds recorded recently (Jílek et al. 2015, 114, fig. 186; Droberjar 2015, 113, fig. 11:7; Iwanicki 2015, 113, pl. IV:7; Iván 2017; Tóth 2018)22 add up to a total of a little less, or a little over 100 specimens; out of this number, from the terri-

${ }^{22}$ Also personal comm. from Barbara Niezabitowska-Wiśniewska (Lublin), Konstantin Skvortsov (Kaliningrad), Joanna Zagórska-Telega (Kraków) and Marcin Biborski (Kraków). 


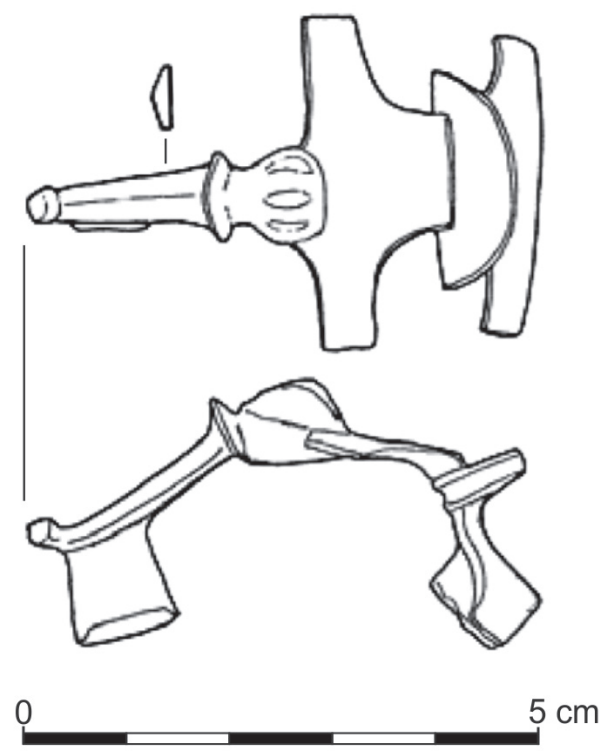

Fig. 15. An ancient 'repairing' of an Almgren 43 brooch, from site Plandište near Cerić, Croatia (after Vulić 2012)

tory of the Przeworsk culture and from 'barbarian' sites on the middle Danube we have a little over thirty specimens each (Fig. 17). In comparison, the group of almost 370 of these brooches discovered 'by accident' in Ukraine is amazing (Fig. 18). All of them, except for one silver specimen, are made of copper alloy, many decorated with silver or gold foil. This huge disproportion in the number of finds recorded in these two main regions of occurrence of Almgren 129 brooches, with an intervening zone in south-eastern Poland, where they are virtually not recorded, and finally, the lack of a cultural context for the brooches found in Ukraine create a picture that cannot be interpreted as yet. Particularly unexpected is the virtually absence of Almgren 129 brooch finds in the source territory of the Wielbark culture, complete with eastern Mazowsze, Podlasie and the eastern Lublin Region, sized by Wielbark people in phase B2/C1-C1a. In the light of that almost ten brooches of this type recorded in the territory of the western Balts must particularly attract our attention ${ }^{23}$.

There are many more questions, variously detailed that I left out from the present discussion. For example, there is the wide distribution range -in Ukraine, all the way to the Black Sea - of buckles with a double tongue (Andrzejowski, Madyda-Legutko 2013; Bruâko, Dzigovskij, Madyda-Legutko 2018, 32-35, figs. 7 and 8), and openwork strap fittings ${ }^{24}$; also, of different forms of brooches with a bull-head foot; these forms definitely have a connection to the Wielbark-Przeworsk and West Balt zone ${ }^{25}$. At least eight brooches of mixed form of Almgren's group II

${ }^{23}$ The Balt lands could be a source area of an Almgren 129 brooch registered at an online auction as found on Gotland (http://www.ebay.com/itm/Viking-ancient-3-brooches-fibula-1-2-century-ADrare-Northern-Europe-/332230147076; access 12.06.2017).

${ }^{24}$ For the strap ends with openwork decoration from Ukraine see Oniŝuk 2018, 158, photo 63:3.4, pl. V:7.8; Bruâko, Dzigovskij, Madyda-Legutko 2018, 35, figs. 5:2 and 9-11. Several openwork belt plates and strap ends of copper alloy found in Ukraine are known from online auctions only. For 'barbarian' openwork belt fittings see Madyda-Legutko 2009; 2011, passim; 2017, 446, figs. 1:2 and 3:2; Andrzejowski, Madyda-Legutko 2018, 69, fig. 9:1c.

${ }_{25}$ The very one published brooch comes from middle Dnieper area (Magomedov, Kuštan 2002), 


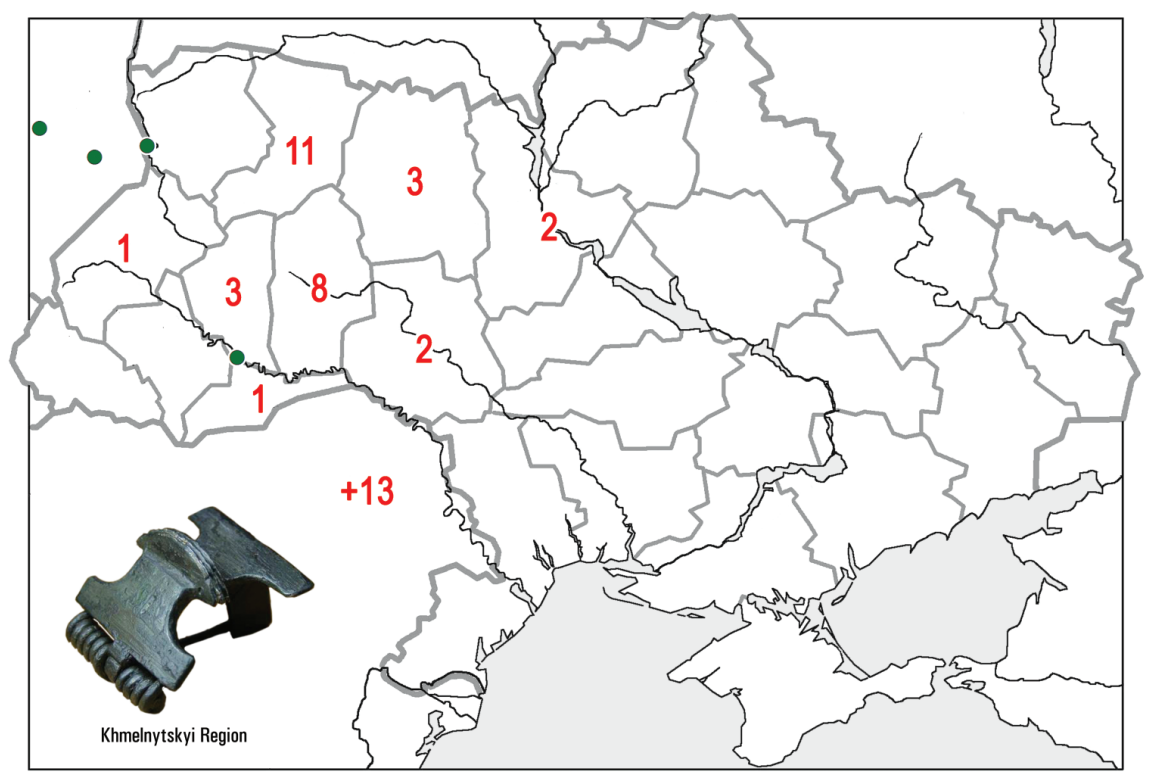

Fig. 16. Distribution of brooches type Almgren 43 known from online auctions (www.violity. com; status 06.2019) within the administrative regions (область) of Ukraine. For the green points see Fig. 14. Photo after www.violity.com

and group IV found in western Ukraine (Fig. 19) evidence both a migration from the east-Przeworsk zone and a transfer of the pattern. Distribution of such brooches within the 'pure' Przeworsk culture area (Fig. 7) shows that this movement may lead through the south-eastern part of contemporary Poland.

Nevertheless, in the light of what we know at present, the following facts become clear:

- the process of the expansion of the Wielbark culture in - generally speaking - south-eastern direction was probably much more complicated than we used to think; the key to improving our understanding of this process could be by better recognizing the archaeological image of western Ukraine at the turn of the Early and Late Roman Period;

- the involvement of the Przeworsk element in this expansion in western Ukraine calls further fieldwork and analysis; the fantastic burial assemblage from Karìv/Kapìs near Rava-Ruska - excavated recently by Yaroslav Onyshchuk

while more than 15 such brooches from Ukraine, mostly from western regions, and one possibly from Belarus, were registered in online auctions. For brooches with bull heads recently see Andrzejowski, Cieśliński 2007, 292-299, figs. 14-19; Mączyńska 2011, 50-51, fig. 21, list 10; Nowakowski 2016. 


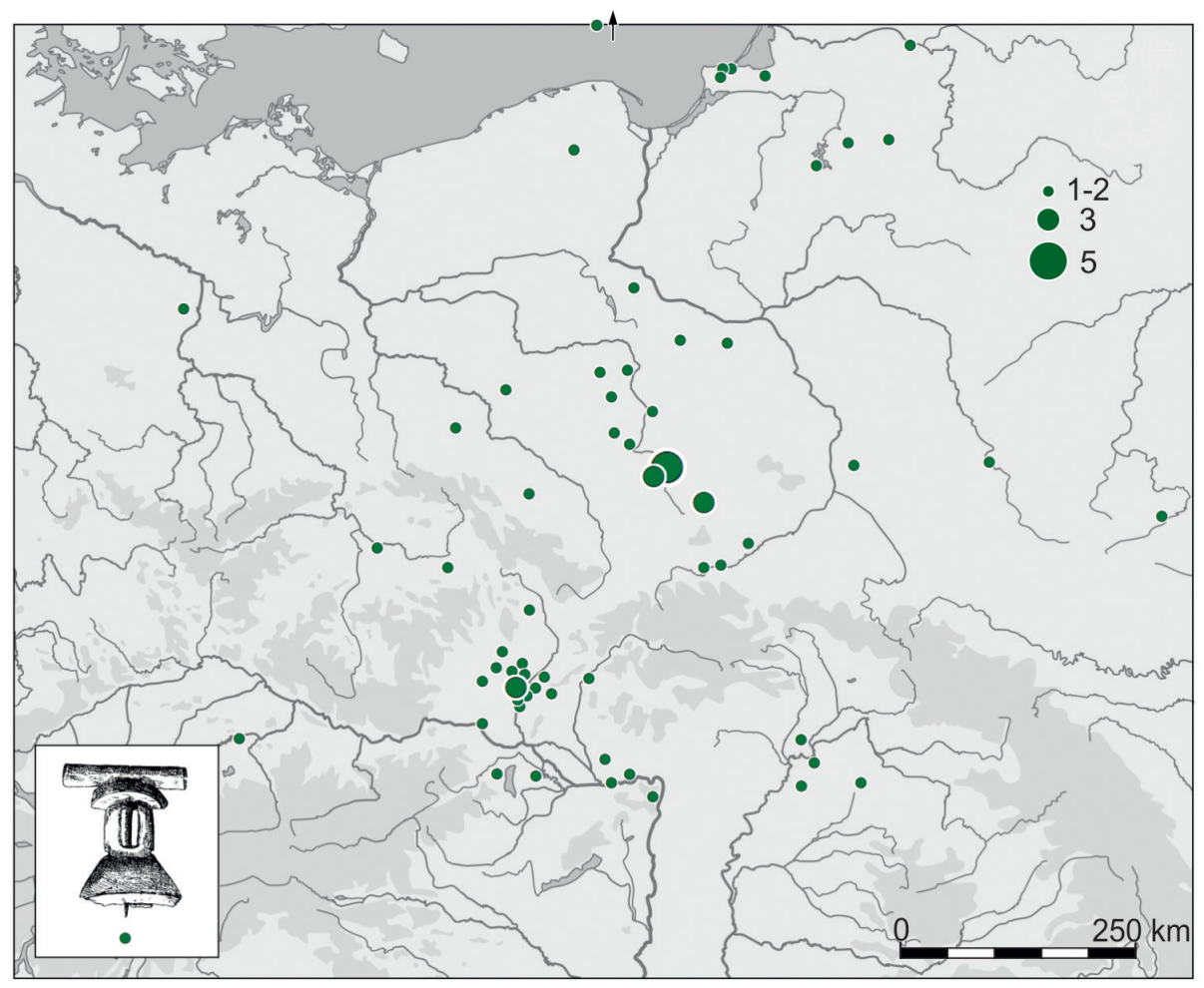

Fig. 17. Distribution of brooches type Almgren 129. Acc. to Mączyńska 2011, Rájtar 2015, Tejral 2015, and Iván 2017, with additions (base map after Mączyńska 2011)

(Oniŝuk 2018, 139-182, figs. 14-20, photo 51-68, pls. II-XII) - is a reflection of evidently many-sided, transregional contacts kept up by the local communities;

- and finally, a little a side note, there is the question of the protection of the archaeological heritage; in a period when illegal metal detecting is unstoppable and beyond any control probably everywhere in Europe we cannot sit back and watch. Leaving the ethical and legal aspects of the 'black archaeologists' activity aside, it should be noted that the artefacts they dug up are not illegal per se. Therefore, professional archaeology must develop a model for registering and studying them.

Fig. 19. Distribution of mixed form of brooches Almgren group II and group IV known from online auctions (www.violity.com; status 06.2019) within the administrative regions (область) of Ukraine. Photo after www.violity.com 


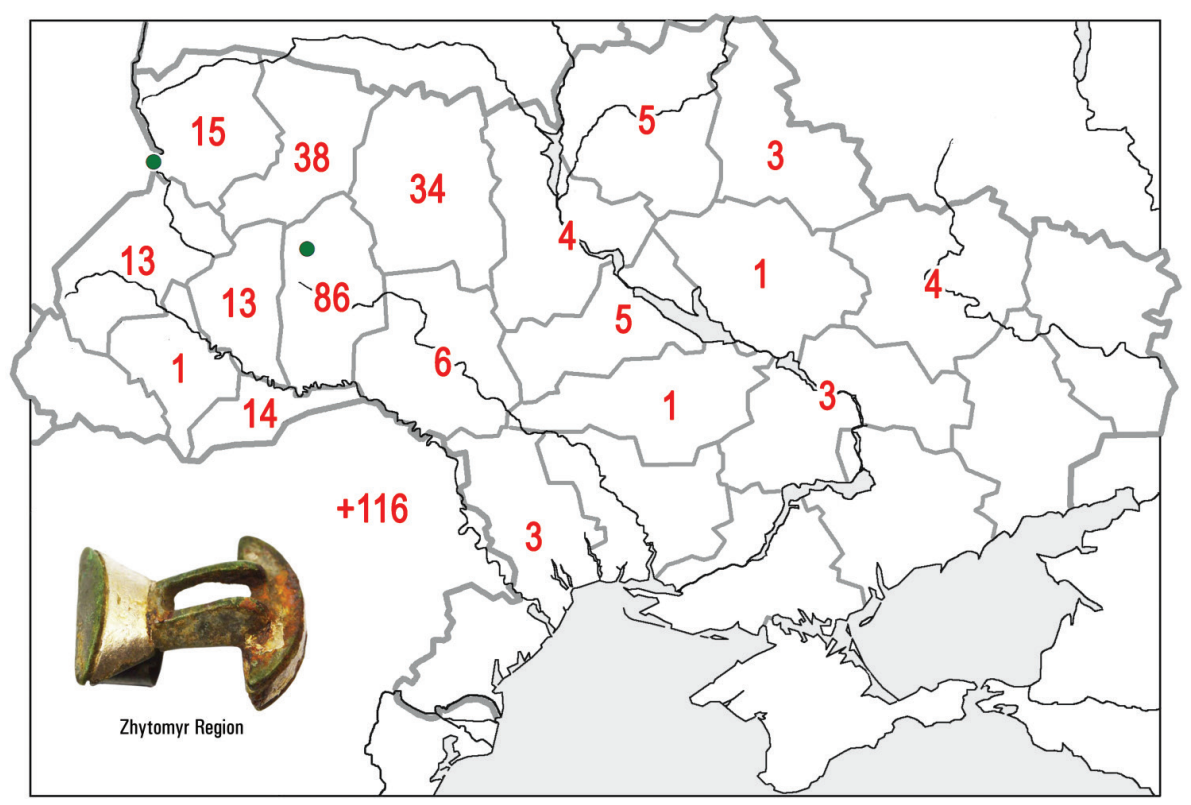

Fig. 18. Distribution of brooches type Almgren 129 known from online auctions (www.violity. com; status 06.2019) within the administrative regions (область) of Ukraine. For the green points see Fig. 17. Photo after www.violity.com

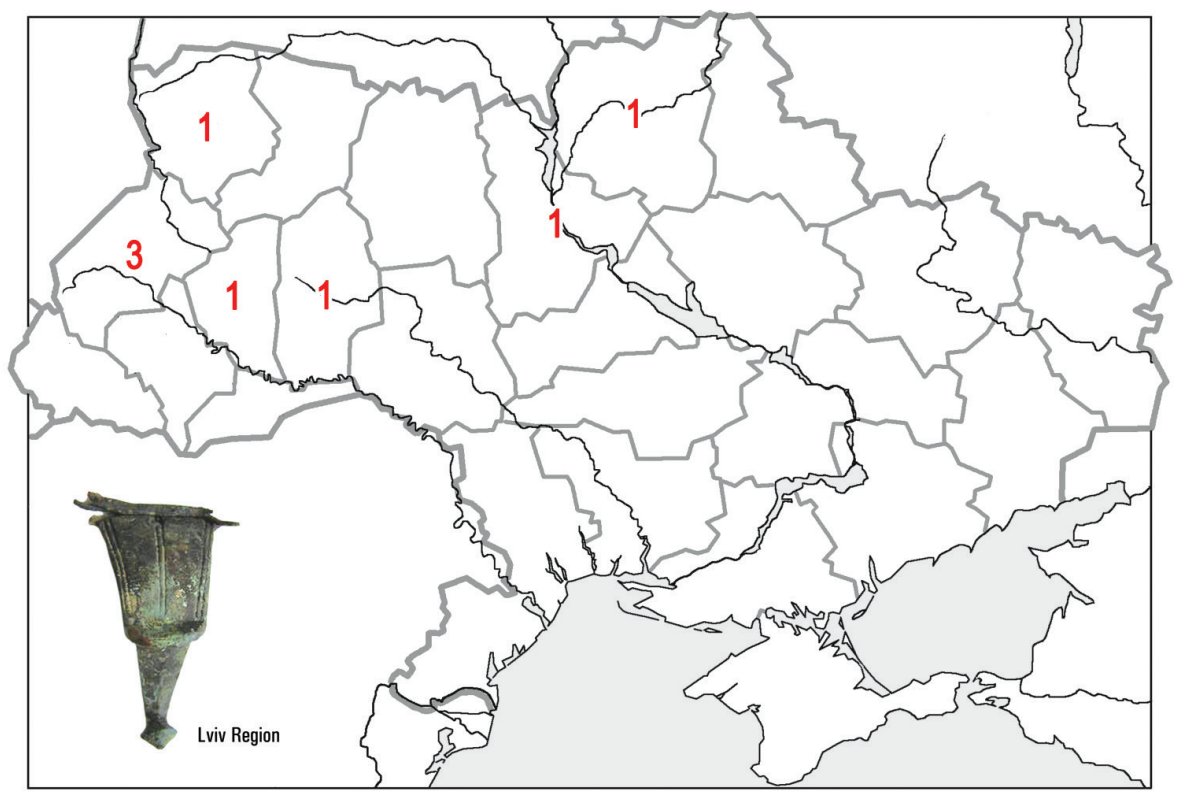




\section{REFERENCES}

Andrzejowski J.

1989 Zagadnienie kontynuacji cmentarzysk $w$ wschodniej strefie kultury przeworskiej, [in:] Kultura wielbarska $w$ mtodszym okresie rzymskim (materiaty z konferencji), v. 2, J. Gurba, A. Kokowski (eds.), Lublin, p. 103-125.

1994a Powiazania kultur przeworskiej $i$ wielbarskiej $w$ świetle znalezisk bransolet, [in:] Kultura przeworska, J. Gurba, A. Kokowski (eds.), Lublin, p. 317-341.

1994b Zapinki o cechach mieszanych II i IV grupy Almgrena, [in:] Barbaricum 3, Warszawa, p. 87-129.

1997 Cmentarzysko kultury przeworskiej w Todzi, gm. Kadzidto, woj. ostrotęckie, stan. 2, Wiadomości Archeologiczne 53(2), p. 101-126.

1998 Nadkole 2. A Cemetery of the Przeworsk Culture in Eastern Poland, Monumenta Archaeologica Barbarica 5, Kraków.

2001a Wschodnia strefa kultury przeworskiej - próba definicji, Wiadomości Archeologiczne 54 (1995-1998), p. 59-87.

2001b Przemiany osadnicze $i$ kulturowe na wschodnim Mazowszu i południowym Podlasiu u schyłku starożytności, [in:] Najstarsze dzieje Podlasia w świetle źródet archeologicznych, B. Bryńczak, P. Urbańczyk (eds.), Siedlce, p. 95-136.

2005 Liwiec river as axis of local settlement structures of the Przeworsk and Wielbark Cultures, [in:] Wasserwege: Lebensadern - Trennungslinien, Schriften des Archäologischen Landesmuseums, Erg.-Reihe 3, C. von Carnap-Bornheim, H. Friesinger (eds.), Neumünster, p. 231-252.

2006a Nekropola ze schytku starożytności w Modle koło Mławy, [in:] Pogranicze trzech światów. Kontakty kultur przeworskiej, wielbarskiej i bogaczewskiej w świetle materiałów z badań i poszukiwań archeologicznych, Światowit, Suppl. Series P: Prehistory and Middle Ages 14, W. Nowakowski, A. Szela (eds.), Warszawa, p. 15-44.

2006b Kołozab, stanowisko 3. Cmentarzysko kultury przeworskiej i kultury wielbarskiej na Mazowszu Ptockim, Warszawa (unpubl. typescript in the Iron Age Dept. State Archaeological Museum in Warsaw).

2007 Pod wodza Filimera, czyli osadnicy wielbarscy na Mazowszu i Podlasiu, [in:] Nowe materiaty i interpretacje, stan dyskusji na temat kultury wielbarskiej, M. Fudziński, H. Paner (eds.), Gdańsk, p. 229-258.

2009 Nekropola w Modle a późna faza kultury przeworskiej na pótnocnym Mazowszu (unpubl. PhD, Intitute of Archaeology, University of Warsaw).

2010 The Przeworsk Culture. A Brief Story (for the Foreigners, [in:] Worlds Apart? Contacts across the Baltic Sea in the Iron Age. Network Denmark-Poland, 20052008, Nordiske Fortidsminder C/7, U. Lund Hansen, A. Bitner-Wróblewska (eds.), København-Warszawa, p. 59-110.

2017 Ad vocem: Orbis Barbarorum. Studia ad archaeologiam Germanorum et Baltorum temporibus Imperii Romani pertinentia Adalberto Nowakowski dedicate, Monumenta Archaeologica Barbarica, Series Gemina VI, J. Andrzejowski, C. von Carnap-Bornheim, A. Cieśliński, B. Kontny, (eds.), Warszawa-Schleswig, p. 421-430.

2019 The Gothic migration through Eastern Poland - archaeological evidences, [in:] Interacting Barbarians. Contacts, Exchange and Migrations in the First Millennium AD, Neue Studien zur Sachsenforschung 9, A. Cieśliński, B. Kontny (eds.), Warszawa-Braunschweig, p. 227-239. 
Andrzejowski J., Cieśliński A.

2007 Germanie $i$ Battowie u schytku starożytności. Przyjazne zwiqzki czy wrogie sqsiedztwo?, [in:] Kultura bogaczewska w 20 lat później. Materiały z konferencji, Warszawa, 26-27 marca 2003, Seminarium Bałtyjskie I, A. Bitner-Wróblewska (ed.), Warszawa, p. 279-319.

Andrzejowski J., Kokowski A., Leiber Ch. (eds.)

2004 Wandalowie - strażnicy bursztynowego szlaku. Państwowe Muzeum Archeologiczne w Warszawie, 8 marca - 16 czerwca 2004. Katalog wystawy, Lublin-Warszawa.

Andrzejowski J., Madyda-Legutko R.

2013 Bronze Belt Buckles with Doubled Tongue between Western Scandinavia and the Black Sea. In Search of Local and Inter-Regional Connections during the Roman Period, [in:] Inter Ambo Maria. Northern Barbarians from Scandinavia towards the Black Sea, Kulturhistoriske rapporter 15, I. Khrapunov, F-A. Stylegar (eds.), Kristiansand-Simferopol 2013, p. 6-25.

2018 Zur Mobilität von Kriegern am Übergang von der älteren zur jüngeren römischen Kaiserzeit im Lichte der Verbreitung der Doppeldornschnallen, Študijné zvesti Archeologického ústavu Slovenskej akadémie vied 64, p. 53-78.

Bakker, L.

2002 Zeugnisse des Handels. Neues aus der rätischen Hauptstadt AELIA AVGVSTA (Augsburg), [in:] Menschen, Zeiten, Räume - Archäologie in Deutschland, Stuttgart, W. Menghin, D. Planck (eds.), p. 262-264.

Balke B.

1971 Żeńskie (?) cmentarzysko z okresu późnorzymskiego w miejscowości Kłoczew, pow. Ryki, Materiały Starożytne i Wczesnośredniowieczne I, 3, p. 17-362.

Belâvec V.G.

2007 (V.G. Belevec) K izučenî̂ pamâtnikov vel'barskoj kul'tury v Belarusi, [in:] Nowe materiaty i interpretacje, stan dyskusji na temat kultury wielbarskiej, M. Fudziński, H. Paner (eds.), Gdańsk, p. 293-345.

2016 Nasel'nìctva vel'barskaj kul'tury y̆ gìstoryka-kul'turnym razvìccì zâmel' Belarusì rubâžu II/III - pačatku V st. n.è., [in:] Slavâne na territorii Belarusi $v$ dogosudarvennyj period. K 90-letiû so dnâ roždeniâ doktora istoričeskih nauk, professora Leonida Davidoviča Pobolâ. Kniga 1, O.N. Levko, V.G. Belevec (eds.), Minsk, p. 384-450.

Beliavets V., Przybyła M.J., Voroniatov S.

2018 Gold rings from Pilipki in Podlasie: some remarks on connections between the Wielbark Culture and Scandinavia at the close of the Early and in the beginnings of the Late Roman Period, [in:] Studia Barbarica. Profesorowi Andrzejowi Kokowskiemu w 65. rocznice urodzin, v. 1, B. Niezabitowska-Wiśniewska, P. Łuczkiewicz, S. Sadowski, M. Stasiak-Cyran, M. Erdrich (eds.), Lublin, p. 158-187.

Bitner-Wróblewska A.

1999 Elementy bałtyjskie na cmentarzysku w Paprotkach Kolonii, stan. 1, woj. warmińsko-mazurskie. Przyczynek do kontaktów battyjsko-przeworskich, [in:] CoMHLAN. Studia z archeologii okresu przedrzymskiego i okresu wptywów rzymskich w Europie Środkowej dedykowane Teresie Dabrowskiej w 65. rocznicę urodzin, J. Andrzejowski (ed.), Warszawa, p. 109-114.

Blume E.

1912 Die germanischen Stämme und die Kulturen zwischen Oder und Passarge zur römischen Kaiserzeit, I Teil: Text, Mannus-Bibliothek 8, Würzburg. 
Born H.

1977 Material und Herstellungstechnik antiker Melonenperlen, [in:] Festschrift HansJörgen Hundt zum 65. Geburtstag, Teil 2: Römerzeit, Jahrbuch des RömischGermanischen Zentralmuseums Mainz 22, p. 134-140.

Bruâko I., Dzigovskij A., Madyda-Legutko R.

2018 Central European Belt Fittings from Sarmatian Burial at Kartal on the Lower Danube, Wiadomości Archeologiczne 69, p. 25-49.

Cieśliński A.

2016 The society of Wielbark culture, AD 1-300, [in:] The Past Societies. Polish lands from the first evidence of human presence to the Early Middle Ages 4: 500 BC-500 $A D$, A. Rzeszotarska-Nowakiewicz (ed.), Warszawa, p. 217-255.

Dąbrowska T.

1981 Zmiany kulturowe prawobrzeżnego Mazowsza i Podlasia w okresie wptywów rzymskich, Wiadomości Archeologiczne 45(1), p. 45-58.

1995 Późne odmiany fibul silnie profilowanych w Polsce, Wiadomości Archeologiczne 53(1), (1993-1994), p. 3-34.

1997 Kamieńczyk. Ein Gräberfeld der Przeworsk-Kultur in Ostmasowien, Monumenta Archaeologica Barbarica 3, Kraków.

1998 Die kräftig profilierten Fibeln Almgren Gruppe IV, Fig. 74-84 (Trompetenfibeln) - mit einem Ausblick auf die östlichen Formen, [in:] 100 Jahre Fibelformen nach Oscar Almgren. Internationale Arbeitstagung 25.-28. Mai 1997 in Klein Machnow, Land Brandenburg, Forschungen zur Archäologie im Land Brandenburg 5, Wünsdorf [2002], p. 149-156.

2003 Przeworsk-Kultur. Jüngere vorrömische Eisenzeit. Frühe Römische Kaiserzeit, [in:] Reallexikon der Germanischen Altertumskunde 23, Berlin-New York, p. 540-553.

Dłubakowski, Z.

2005 Stanowisko wielokulturowe w miejscowości Pajewo-Szwelice, woj. mazowieckie, Warszawskie Materiały Archeologiczne 9, Warszawa, p. 9-218.

Droberjar E.

2015 Markomannen und superiores barbari in Třebusice und Jevíčko zur Zeit der Markomannenkriege. Zur Problematik der Übergangsstufe B2/C1 in Böhmen und Mähren, Přehled výzkumů 56(2), p. 43-101.

Godłowski K.

1985 Przemiany kulturowe $i$ osadnicze $w$ południowej $i$ środkowej Polsce $w$ mtodszym okresie przedrzymskim i w okresie wpływów rzymskich, Wrocław.

1992a Die Przeworsk-Kultur, [in:] Beiträge zum Verständnis der Germania des Tacitus, Teil II, Abhandlungen der Akademie der Wissenschaften in Göttingen, Phil.Hist. Klasse, Dritte Folge 195, Göttingen, p. 9-90.

1992b Germanische Wanderungenim 3.Jh.v.Chr.6.Jh.n.Chr. undihre Wiederspiegelung in den historischen und archäologischen Quellen, [in:] Peregrinatio Gothica III, Universitetets Oldsaksamlings Skrifter, Ny rekke 14, Oslo, p. 53-75.

1994 Die Barbaren nördlich der Westkarpaten und das Karpatenbecken - Einwanderungen, politische und militärische Kontakten, Specimina Nova. Dissertationes ex Instituto Historico Universitatis Quinqueecclesiensis de Iano Pannonio Nominatae 9 (1993), p. 65-89.

Grzymkowski A.

1986 Wstẹpne wyniki badań na birytualnym cmentarzysku ciałopalnym i szkieletowym 
z okresu rzymskiego w Modle, gm. Wiśniewo, woj. Ciechanów, Sprawozdania Archeologiczne 38, p. 223-257.

2005 Zespoły z uzbrojeniem sprzed dwóch tysięcy lat na terenie Ziemi Zawkrzeńskiej, Ziemia Zawkrzeńska 9, Mława, p. 79-119.

Hadaczek K.

1909 Album przedmiotów wydobytych $w$ grobach cmentarzyska ciałopalnego koto Przeworska (z epoki Cesarstwa Rzymskiego), Teka Konserwatorska. Rocznik Grona C.K. Konserwatorów Starożytnych Pomników Galicyi Wschodniej 3(2), Lwów.

Höpken C.

2003 Herstellung quarzkeramischer Melonenperlen im römischen Flottenlager Köln Alteburg: Terminologie - Technologie - Befund, [in:] Römische Keramik. Herstellung und Handel. Kolloquium Xanten, 15.-17.6.2000, Xantener Berichte 13, B. Liesen, U. Brandl (eds.), Xanten, 353-363.

Iván R.

2017 Spony 8. série V. skupiny podl’a O. Almgrena v stredodunajskej oblasti, [in:] Řimské a germánské spony ve střední Evropě (Archeologie barbarů 2012) / Römische und germanische Fibeln in Mitteleuropa (Archäologie der Barbaren 2012), Spisy Archeologického ústavu AV ČR Brno 53, E. Droberjar, B. Komoróczy (eds.), Brno, p. 291-319.

Iwanicki P.

2015 Kształtowanie sie osadnictwa kultury bogaczewskiej $w$ dolinie Gotdapy, na podstawie badań z lat 2008-2011, [in:] Materiaty do Archeologii Warmii i Mazur 1, S. Wadyl, M. Karczewski, M. Hoffmann (eds.), Warszawa-Białystok-Olsztyn, p. 109-117.

Jaskanis J.

2005 Krupice. Ein Gräberfeld der Przeworsk- und Wielbark-Kultur in Ostpolen, Monumenta Archaeologica Barbarica 10, Warszawa.

Jílek J., Vokolek V., Schmidtová D., Černá H., Janošek Kašpárek F., Burgert P.

2015 Výběr z nálezů, [in:] Proti proudu času. Pardubicko v pravěku a raném strědověku, J. Jílek (ed.), Pardubice.

Kempisty A.

1968 Birytualne cmentarzysko $z$ późnego okresu rzymskiego $w$ miejscowości BrulinoKoski, pow. Ostrów Mazowiecka, Wiadomości Archeologiczne 32(3-4) (19661967), p. 409-449.

Kokowski A.

1990 Trzeci sezon badań stanowiska nr 1 w Drażgowie, woj. lubelskie, Sprawozdania z badań Katedry Archeologii UMCS w 1990 roku, Lublin, p. 26-29.

1991 Lubelszczyzna $w$ młodszym okresie przedrzymskim $i w$ okresie rzymskim, Lubelskie Materiały Archeologiczne 4, Lublin.

1999 Vorschlag zur relativen Chronologie der südöstlichen Kulturen des „Gotenkreises” (Die Forschungsergebnisse zur Mastomęcz-Gruppe in Polen), [in:] Die Sintana de Mureş-Černjachov-Kultur. Akten des Internationalen Kolloquiums in Caputh vom 20. bis 24 Oktober 1995, G. Gomolka-Fuchs (ed.), Bonn, p. 179-209.

2007 Goci od Skandzy do Campi Gothorum (od Skandynawii do Pótwyspu Iberyjskiego), Warszawa.

2010 Die Wielbark-Kultur - die Goten in Mittel- und Osteuropa, [in:] Worlds Apart? Contacts across the Baltic Sea in the Iron Age. Network Denmark-Poland, 
Kontny B.

2005-2008, Nordiske Fortidsminder C/7, U. Lund Hansen, A. Bitner-Wróblewska (eds.), København-Warszawa, p. 59-110.

2016 Przeworsk culture society and its long-distance contacts, AD 1-350, [in:] The Past Societies. Polish lands from the first evidence of human presence to the Early Middle Ages 4: 500 BC-500 AD, A. Rzeszotarska-Nowakiewicz (ed.), Warszawa, p. 163-216.

Kozak D.N.

1984 Pševors'ka kul'tura u verhn'omu Podnistrov'ï ì zachidnomu Pobužžì, Kï̀v.

1993 Pševors'kaâ kul'tura, [in:] Slavâne i ih sosedi v konce I tysâčeletiâ do n.è. - pervoj polovine I tysâčeletiâ n.è., Arheologiâ SSSR, Moskva, p. 53-66.

2008 Venedi, Kï̀v.

Kuharenko Û.V.

1980 Mogil'nik Brest-Trišin, Moskva.

Kurpiewski A., Rakoczy J.

2015 Materiaty kultury przeworskiej z Perkowa na Kujawach, Torun.

Kuśnierz, J.

2005 Nieznana kolekcja zabytków z młodszego okresu przedrzymskiego, okresu rzymskiego $i$ wędrówek ludów z Topornicy stanowiska 21 i 22, [in:] Europa Barbarica. Ćwierć wieku archeologii w Masłomęczu, Monumenta Studia Gothica 4, P. Łuczkiewicz, M. Gładysz-Juścińska, M. Juściński, B. Niezabitowska, S. Sadowski (eds.), Lublin, p. 233-247.

Lasota A.

2011 Cmentarzysko zokresu rzymskiego w Gaci koło Przeworska w świetle nowych badań, [in:] Archeologie barbarů 2010: Hroby a pohřebiště Germánů mezi Labem a Dunajem. sborník př́spěvků ze VI Protohistorické konference, Hradec Králové, 6. - 9. záři 2010, Studia Archaeologica Suebica 1, E. Droberjar (ed.), Olomouc, p. 155-161.

2014 Grób wojownika z cmentarzyska w Gaci, pow. przeworski. Przyczynek do studiów nad lokalnymi formami okuć tarczy w kulturze przeworskiej, [in:] Honoratissimum assensus genus est armis laudare. Studia dedykowane Profesorowi Piotrowi Kaczanowskiemu z okazji siedemdziesiatej rocznicy urodzin, R. Madyda-Legutko, J. Rodzińska-Nowak (eds.), Kraków, p. 151-160.

Lasota A., Stempniak S.

2015 Nowo odkryte cmentarzysko $z$ wczesnego $i$ młodszego okresu wpływów rzymskich w Ostrowie, stan. 21, gm. Przemyśl, woj. podkarpackie, [in:] Barbari superiores et inferiores. Archeologia barbarzyńców 2014. Procesy integracji środkowoeuropejskiego Barbaricum. Polska - Czechy - Morawy - Stowacja, L. Tyszler, E. Droberjar (eds.), Łódź-Wieluń, p. 225-233.

Levada, M.E.

2007 Ob osobennostâh pružinnogo apparata nekotoryh tipov fibul (fibuly so "srednej" tetivoj), Bosporskie issledovaniâ 16, Simferopol'-Kerč', p. 239-258.

Maciałowicz A.

2016 It's a Man's World... Germanic societies of the Jastorf and the Przeworsk cultures in southern and central Poland (300 BC-10 AD), [in:] The Past Societies. Polish lands from the first evidence of human presence to the Early Middle Ages 4: 500 $B C-500 A D$, A. Rzeszotarska-Nowakiewicz (ed.), Warszawa, p. 71-110.

Maciałowicz A., Woźniak M.

2015 Vanishing weapons. The cemetery at Kleszewo and 'pacifstic' burial customs in 
the Przeworsk Culture during the Late Pre-Roman Period, [in:] Waffen - Gewalt - Krieg. Beiträge zur Internationalen Tagung der AG Eisenzeit und des Instytut Archeologii Uniwersytetu Rzeszowskiego - Rzeszów 19.-22. September 2012, Beiträge zur Ur- und Frühgeschichte Mitteleuropas 79, S. Wefers, M. Karwowski, J. Fries-Knoblach, P. Trebsche, P.C. Ramsl (eds.), Langenweissbach, p. 229-269. Madyda-Legutko R.

2009 Uwagi o ornamentyce ażurowej w kręgu zachodniobałtyjskim, [in:] Battowie $i$ ich sqsiedzi. Marian Kaczyński in memoriam, Seminarium Bałtyjskie 2, A. BitnerWróblewska, G. Iwanowska (eds.), Warszawa, p. 773-786.

2011 Studia nad zróżnicowaniem metalowych części pasów w kulturze przeworskiej. Okucia końca pasa, Kraków.

2017 Niestandardowe zestawy metalowych części pasa $z$ obszaru kultury przeworskiej $z$ przełomu wczesnego i mtodszego okresu rzymskiego, [in:] ORBIS BARBARORUM. Studia ad archaeologiam Germanorum et Baltorum temporibus Imperii Romani pertinentia Adalberto Nowakowski dedicata, Monumenta Archaeologica Barbarica. Series Gemina 6, J. Andrzejowski, C. von Carnap-Bornheim, A. Cieśliński, B. Kontny (eds.), Warszawa-Schleswig, p. 441-451.

Madyda-Legutko R., Rodzińska-Nowak J.

2012 Interkulturelle Beziehungen der Bevölkerung der Przeworsk-Kultur in der Karpatenzone am Übergang von der frühen zu der jüngeren römischen Kaiserzeit am Beispiel des Gräberfeldes von Prusiek, Fst. 25, Gde. Sanok, Přehled výzkumů 53(1), p. 75-87.

2017 Reich verzierte frühkaiserzeitliche Fibeln aus dem südostlichen Polen, [in:] Na hranicích impéria/ Extra fines imperii. Jaroslavu Tejralovi k 80. narozeninám, Brno, p. 301-313.

Madyda-Legutko R., Rodzińska-Nowak J., Zagórska-Telega J.

2009 Prusiek, Fst. 25, Gde. und Kr. Sanok, Woiw. Podkarpackie-das erste Gräberfeld der Bevölkerung der Przeworsk-Kultur in den polnischen Karpaten, Recherches Archeologiques NS 1, p. 295-309.

2010 Złote wisiorki z cmentarzyska ludności kultury przeworskiej w Prusieku, stan. 25, gm. Sanok, [in:] TERRA BARBARICA. Studia ofiarowane Magdalenie Maczyńskiej w 65. rocznice urodzin, Monumenta Archaeologica Barbarica. Series Gemina 2, A. Urbaniak, R. Prochowicz, I. Jakubczyk, M. Levada, J. Schuster (eds.), ŁódźWarszawa, p. 387-395.

2013 New data concerning the cultural situation in the basin of the Upper San River during the Roman Period, A nyíregyházi Jósa András Múzeum Évkönyve 55, p. 409-422.

Magomedov B.V., Kuštan D.P.

2002 Fìbula z golovkoû bika z čerkaskoï oblasti, Arheologiâ 3/2002, p. 66-67. Mączyńska M.

2003 Przeworsk-Kultur. Jüngere und späte Römische Kaiserzeit, [in:] Reallexikon der Germanischen Altertumskunde 23, Berlin-New York, p. 553-567.

2004 Bemerkungen über einige Typen der Augenfibeln im Barbaricum, [in:] Zentrum und Peripherie - Gesellschaftliche Phänomene in der Frühgeschichte. Materialien des 13. Internationalen Symposiums „Grundprobleme der frühgeschichtlichen Entwicklung im mittleren Donauraum"Zwettl, 4.-8. Dezember 2000, Mitteilungen der Prähistorischen Kommission 57, H. Friesinger, A. Stuppner (eds.), Wien, p. 211-240. 
2007 Wielbark-Kultur, [in:] Reallexikon der Germanischen Altertumskunde 34, BerlinNew York, p. 1-20.

2011 Der frühvölkerwanderungszeitliche Hortfund aus Eubiana, Kreis Kościerzyna (Pommern), Bericht der Römisch-Germanischen Kommission 90 (2009), p. 7-481.

Natuniewicz-Sekuła M.

2018 Weklice, stan. 7, pow. elblaski, woj. warmińsko-mazurskie. Badania w latach 2015-2016, Światowit 13-14 (54-55) (2015-2016), p. 235-240.

Nowakowski W.

2016 Items with the ox-head on the shores of the Baltic sea in the Roman Period, Archaeologia Baltica 23, p. 129-139.

Okulicz J.

1965a Plemiona grupy nidzickiej kultury grobów jamowych (w okresie od końca II $w$. przed nasza erq do $V w$. n.e.), unpubl. $\mathrm{PhD}$, University of Warsaw; CD edition [in:] Pogranicze trzech światów. Kontakty kultur przeworskiej, wielbarskiej, $i$ bogaczewskiej $w$ świetle materiałów $z$ badań $i$ poszukiwań archeologicznych, Światowit Suppl, Series P: Prehistory and Middle Ages 14, W. Nowakowski, A. Szela (eds.), Warszawa (2006).

1965b Rostki I, distr. d’Ostrotęka, dép. de Varsovie, Inventaria Archaeologica, Pologne 15, Warszawa-€ódź, pl. 88.

1970 Studia nad przemianami kulturowymi $i$ osadniczymi $w$ okresie rzymskim na Pomorzu Wschodnim, Mazowszu i Podlasiu, Archeologia Polski 15(2), p. 419-497.

Olędzki M.

1987 Chronologia, typologia i rozprzestrzenienie zapinek typu Nadkole, Fontes Archa-

Oniŝuk Â.ì. eologici Posnanienses 35, p. 139-148.

2018 Naselennâ Zahìnoï Volinì ta Zahìdnogo Podillâ u peršì polovinì I tis. n. e.: kul'turno-istoričnij aspekt. Monografiâ, L'viv.

Pfeiffer-Frohnert U.

2002 „Mit Augen am Fuß und mit Wulst statt Scheibe."Verbreitung und Zeitstellung der preußischen Nebenserie A 57-61 und ihrer Varianten, [in:] 100 Jahre Fibelformen nach Oscar Almgren. Internationale Arbeitstagung 25.-28. Mai 1997 in Klein Machnow, Land Brandenburg, Forschungen zur Archäologie im Land Brandenburg 5, Wünsdorf [2002], p. 125-134.

Pieta K., Švihurová M.

2019 Influence of the Przeworsk culture in the Púchov culture milieu, Acta Archaeologica Carpathica 54, p. 107-128.

Rajtár J.

2013 Das Gold bei der Quaden, [in:] Macht des Goldes, Gold der Macht. Herrschaftsund Jenseitsrepräsentation zwischen Antike und Frühmittelalter im mittleren Donauraum. Akten des 23. Internationalen Symposiums der Grundprobleme der frühgeschichtlichen Entwicklung im mittleren Donauraum, Tengelic, 16.19.11.2011, Forschungen zu Spätantike und Mittelalter 2, M. Hardt, O. HeinrichTamáska (eds.), Weinstadt, p. 125-150.

2015 Germánske nálezy z rímskeho drevozemného tábora v Iži, Zborník Slovenského národného múzea 109 - Archeológia 25, p. 379-399.

2018 Die Fibeln vom Typ Almgren 43, [in:] STUDIA BARBARICA. Profesorowi Andrzejowi Kokowskiemu $w$ 65. rocznice urodzin, v. 2, B. Niezabitowska-Wiśniewska, P. Łuczkiewicz, S. Sadowski, M. Stasiak-Cyran, M. Erdrich (eds.), Lublin, p. 52-72. 
Rákoš J.

2018 Predbežné výsledky výskumu pohrebiska przeworskiej kultúry v Rankovciach, unpubl. paper at the conference Movement and Stabilization. Przeworsk Culture in the Upper Tisa River Basin in the Roman Period, Sanok, 23-25.05.2018.

Rodzińska-Nowak J.

2016 Societies in the lands of Poland, from 350 AD until 500 AD, [in:] The Past Societies. Polish lands from the first evidence of human presence to the Early Middle Ages 4:

Ŝkin M.B. $500 B C-500 A D$, A. Rzeszotarska-Nowakiewicz (ed.), Warszawa, p. 307-344.

2005 Gotskij put' (goty, Rim i černâhovskâ̂ kul'tura), Sankt-Peterburg.

Tejral J.

2015 Some remarks on the transitional phase between Early Roman and Late Roman Periods in the region north of the Middle Danube, Přehled výzkumů 56(2), p. 43-101.

Tomaszewska I.

1988 Groby kultury wielbarskiej na cmentarzysku w Kotozębiu, gm. Suchocin, woj. ciechanowskie, [in:] Kultura wielbarska w mtodszym okresie rzymskim (materiaty $z$ konferencji), v. 1, J. Gurba, A. Kokowski (eds.), Lublin, p. 105-116.

Tóth A.B.

2018 On the traces of Germanic cemeteries in Northeast Hungary (unpubl. paper at the conference Movement and Stabilization, Przeworsk Culture in the Upper Tisa River Basin in the Roman Period, Sanok, 23-25.05.2018.

Twardo S.

2003 Zapinki oczkowate serii pruskiej z terenu pótnocno-wschodniego Mazowsza, Studia i Materiały Archeologiczne 11, Warszawa, p. 164-247.

Voss H.-U.

2007 Das Corpus der römischen Funde im europäischen Barbaricum - zu einigen Aspekten der Fundauswertung, [in:] Archeologie barbarů 2006. Sborník př́spěvků z II. protohistorické konference, České Budějovice 21.-24. 11. 2006, Archeologické výzkumy v jižních Čechách, Suppl. 3, E. Droberjar, O. Chvojka (eds.), České Budějovice, p. 7-26.

2008 Fremd - nützlich - machbar. Römische Einflüsse im germanischen Feinschmiedehandwerk, [in:] Zwischen Spätantike und Frühmittelalter. Archäologie des 4. bis 7. Jahrhunderts im Westen, Reallexikon der germanischen Altertumskunde, Erg.-Bd. 57, S. Brather (ed.), Berlin-New York, p. 343-365.

Vulić H.

2007 The Southernmost Find of Fibula Type Almgren 43, [in:] European Association of Archaeologist. 13th Annual Meeting, Zadar, Croatia 18th-23rd September 2007. Abstracts Book. Programme and Abstracts, Ante Uglešić (ed.), Zadar, p. 241.

2012 Fibule s lokaliteta Plandišta kod Cerića u kontekstu proizvodnje $i$ uloge fibula $u$ rimskom razdoblju, [in:] Opera archaeologica \& historico-topographica / Arheološki i povijesno-topografski radovi, D. Petković (ed.), Acta musei cibalensis 5 NS 3, p. 95-131.

Walther W.

2018 Östliche Elemente im elbgermanischen Thüringen während der jüngeren Römischen Kaiserzeit (unpubl. paper at the conference Schnittstellen Archäologie - Raum und Zeit / Archeologia styków - przestrzeń i czas, Puszczykowo, 16-18.05.2018). 
Wołąiewicz R.

1988 Chronologia ceramiki kultury wielbarskiej, [in:] Kultura wielbarska w mtodszym okresie rzymskim (materiaty z konferencji), v. 1, J. Gurba, A. Kokowski (eds.), Lublin, p. 145-155.

Woźniak M.

2016 Grób 884 z cmentarzyska kultur przeworskiej $i$ wielbarskiej $w$ Kleszewie, pow. puttuski, [in:] Pogranicze trzech światów - Mazowsze u schytku starożytności, Światowit Suppl. Series P: Prehistory and Middle Ages 14, A. Jarzec, W. Nowakowski, A. Szela (eds.), Warszawa, p. 190-209.

2019 Interregional contacts of barbarian societies in the light of materials from the cemetery at Kleszewo in northeastern Masovia, [in:] Interacting Barbarians. Contacts, Exchange and Migrations in the First Millennium AD, Neue Studien zur Sachsenforschung 9, A. Cieśliński, B. Kontny (eds.), Warszawa-Braunschweig, p. 87-203.

Wójcik T.

1982 Pomorskie formy bransolet wężowatych z okresu rzymskiego, Materiały Zachodniopomorskie 24 (1978), p. 35-109.

Ziemlińska-Odojowa W.

1999 Niedanowo. Ein Gräberfeld der Przeworsk- und Wielbark-Kultur in Nordmasowien, Monumenta Archaeologica Barbarica 7, Kraków.

Address of the Author

Jacek Andrzejowski

State Archaeological Museum

in Warsaw

ul. Długa 52 «Arsenał»

00-241 Warszawa, Poland

j.andrzejowski@pma.pl

ORCID ID: 0000-0001-7039-3012 